\title{
On the Fourth Edition of A Dictionary of South African English
}

David L. Gold, Jewish English Archives, New York

Abstract: Having reviewed the first and third editions of $A$ Dictionary of South African English in earlier publications, the author examines the fourth edition. He suggests a number of improvements with respect to several aspects of the dictionary, ranging from superficial, though important, matters (like layout and typography) to the most difficult aspects of Iexicography (definition and etymology).

Keywords: ABBREVIATION, ACRONYM, AFRIKAANS, AMERICAN ENGLISH, BLACK ENGLISH, BRITISH ENGLISH, CONSULTANT VS. RESEARCHER, CONTRASTIVE LINGUISTICS, CORPUS-DELIMITATION, DICTIONARY, DUTCH, ENGLISH, ENTRY HEAD, ETYMOLOGY, GRAPHIC ILLUSTRATION, HEBREW, JEWISH ENGLISH, JUDEZMO; LETTERWORD, LEXICOGRAPHY, NEW NETHERLAND DUTCH, NORTHEASTERN YIDDISH, PRESCRIPTIVISM, SOUTH AFRICAN ENGLISH, WESTERN YIDDISH, YIDDISH

\section{Opsomming: Oor die vierde uitgawe van A Dictionary of South African} English. Die skrywer, wat die eerste en derde uitgawes van $A$ Dictionary of South African English in vroeëre publikasies geresenseer het, ondersoek hier die vierde uitgawe van dié werk. Hy stel 'n aantal verbeterings met betrekking tot verskeie aspekte van die woordeboek voor. Hierdie verbeteringe wissel van kleiner maar belangrike sake (soos uitleg en tipografie) tot die moeilikste aspekte van die leksikografie (definiëring en etimologie).

Sleutelwoorde: AFKORTING, AFRIKAANS, AKRONIEM, AMERIKAANSE ENGELS, BRITSE ENGELS, ENGELS, ETIMOLOGIE, GRAFIESE ILLUSTRASIE, HEBREEUS, JIDDISJ, JOODSE ENGELS, JUDESMO, KONSULTANT VS. NAVORSER, KONTRASTIEWE LINGUISTTEK, KORPUSAFBAKENING, LEKSIKOGRAFIE, LEMMAVORM, LETTERWOORD, NEDERLANDS, NIEUNEDERLANDSE NEDERLANDS, NOORDOOSTELIKE JIDDISJ, SUID-AFRIKAANSE ENGELS, SWART ENGELS, VOORSKRIFTELIKHEID, WESTELIKE JIDDISJ, WOORDEBOEK

\section{Contents}

0. Introduction

1. The boundaries of the corpus

2. Additional material

3. Definitions

4. Identical or similar usages in other varieties of English 
5. Identical or similar usages in other languages

6. Etymologies

7. Prescriptivism

8. The form of entry heads

9. Abbreviations, acronyms, and letterwords

10. Hidden lexemes

11. Blind references

12. Layout and typography

13. Graphic illustration

14. Material of Jewish interest

15. Misprints

16. Conclusions

\section{Introduction}

The fourth edition of A Dictionary of South African English, (Cape Town, Oxford University Press, 1991), written by Jean Branford with William Branford, went to press shortly after a review of the third appeared (Gold 1989a). Consequently, the suggestions for improvement made there (most of which apply to the fourth as well) reached the compilers too late for consideration. Curiously, however, they do not seem to have utilized several relevant articles and notes published earlier (Gold 1981a, 1984a, 1984c, and 1986a). The following suggestions span the gamut from superficial, though important, matters (like layout and typography) to the most difficult aspects of lexicography (definition and etymology).

\section{The boundaries of the corpus}

This being a supplementary dictionary (i.e., not a full dictionary of South African English), its compilers faced the problem confronted by the authors of all partial studies: determining the boundaries of the corpus (cf. their Introduction, p. ix ff.). Many items should unquestionably be included (for instance, robot 'traffic light', because this sense of the word arose in South African English, it is used only there, and it is both current and frequent). Robot 'automaton', on the other hand, a general-English word with a generalEnglish meaning, must be excluded. The problem is not with extreme cases like these, but with the broad gray area in between.1

To some extent, deciding how to treat the gray area depends on one's viewpoint (Gold 1989a: 243-244). A speaker of American English, but not of British English, would be struck by South African English post (as in "Has the post come yet?") because American English uses mail in this context. A speaker of British English would not notice post at all. The compilers state their starting 
point to be British English (p. ix ff.), a logical choice given the fact that South African English is an outgrowth of it and for many years British English was taken to be the English standard in South Africa. In contrast, in choosing the additions suggested below, I have taken American English as a basis for comparison, not only because that happens to be my variety of the language, but also because such a comparison may help to elucidate the influence of Dutch on the English of South Africa and of North America (cf. can't complain, with cross-references, in section 42 ).

To a certain extent, treating the gray area also depends on the nature and the size of the dictionary: diachronic and synchronic dictionaries have different criteria and the more space available the more the gray area may be treated.

A few entries in the fourth edition seem questionable in a work of this nature and size: [1] haj, [2] hadji, [3] halal / halaal, [4] haram / haraam, [5] jihad, [6] karakul, [7] kwacha, [8] kwashiorkor, [9] totem, [10] zakaat, and [11] Zimbabwean. Nos. 1, 2, 3, 4, 5, and 10 are ethnolectalisms in South African English, viz., they are found mostly in the English of Muslims. They are not, however, peculiar or even characteristic of Muslim South African English (when compared to other Muslim varieties of English), hence the only reason for their appearance in this dictionary is that they are not usual in non-Muslim South African English. Yet such a liberal criterion would require the compilers to list several hundred Jewish South African English items (indeed, it is easy to find Jewish South African English items semantically similar to these Muslim usages: haj is similar to aliya; hadji to ole; halal / halaal to kosher; haram / haraam to treyf; and zakaat to tsdoke), but the compilers have, quite correctly, excluded them because they are not particular to Jewish South African English when compared to other varieties of Jewish English. ${ }^{3}$ With respect to nos. 6 and 8, the compilers explain in their Introduction that they list some general-English words which are particularly relevant to South Africa. That is a good idea, but these two are perhaps just over the borderline of relevance. No. 9 is labeled "Not SAE" and that is comment enough. Since nos. 7 and 11 refer to neighboring countries, it is hard to justify their appearance in this dictionary of South African [not Southern African] English. If these words are given, the sky's the limit: why not the names of the currencies and the detoponyms of other neighboring countries too? And where is the cutoff point geographically?

Jean Branford's willingness to record ethnolectal material was mentioned in Gold 1986a: 143 and in this edition the compilers have fortunately continued on that path, even more so than she did in earlier editions. Specifically, South Africa's recent unbanning of certain publications and the important social and political changes which the country is now undergoing led the compilers, as they explain in their Introduction, to include in the fourth edition many hitherto unrecorded or non-White South African English usages and hitherto unpublishable citations. Curiously, however, among the many primary sources laid under contribution for this edition (pp. 394-412), those of Nadine Gordimer are conspicuous by their absence, possibly because her written 
English is so close to the British standard that they provide little specifically South African and what they do contain of this nature has been easily accessible to the compilers from other sources.

Besides adding material in the fourth edition, the compilers have deleted much from the third (the latter is actually larger than its successor). The fourth edition thus only supplements, and does not replace, the third, which should not be neglected.

\section{Additional material}

Here are some items which may be considered worthy of note in future editions:

a bean 'anything'. Slangism used in negative contexts, e.g., "They didn't give us a bean!" Cf. American English beans, as in "They don't care beans about us!"

bootleg 'be a bootlegger'. Also in American English.

Brown 'Colored person'. Count noun. Only the adjective is listed in the fourth edition.

bugger up 'foul up, mess up'. Vulgar. E.g., 'You've certainly buggered things up!" From British English? Cf. the same semantic development in American English fuck up.

Bushman's Christmas 'Friday evening'. An offensive lexeme alluding to widespread drinking at the end of the work week by non-White, especially Colored, workers.

the Cape 'the Cape of Good Hope'.

catapult 'slingshot'. The definiens is the American English equivalent.

cattle hut In recent years, this has been the recommended substitute for Bantu hut, which could also be added (cf. the compilers' remarks on the tendency to avoid the word Bantu because of its association with apartheid).

in commerce 'in business'. The definiendum and the definiens, however, are not quite interchangeable in South African English: in commerce refers to big business and in business to small business. 4 Current American English has only in business, regardless of size.

dhukkum 'black magic'. The sense 'a Malay magician or doctor' is entered. 
diamondiferous 'diamond-bearing'. $O E D 2$ does not say that this word was coined in South Africa, but its first citation, dated 1870, does refer to southern Africa, hence it may well have been coined there.

farm club 'club formed by a farmer for his or her workers, its goal being to improve their physical and spiritual life'.

farm shop 'shop which a farmer runs for his or her workers'. The nearest American English equivalent is company store, which designates a shop run by a company, not a farmer, for its workers.

fence 'to receive stolen goods, act as a fence'. Also in American English.

Juizenberg 'Muizenberg'. Derogatory. Explained in Jewish Linguistic Studies 2: 433. Cf. Jewburg, derogatory name for Johannesburg, discussed in Gold 1986a: 131-132.

Kontak 'a nonpolitical Afrikaner women's organization whose goal is to improve relations between the peoples of South Africa'. The number of organizational names that could be entered is high, hence one must be selective. A few are already given in the fourth and earlier editions.

kultuur 'Afrikaans culture'. Specialization of Afk. kultuur 'culture'.

lead the high life 'live it up'. The definiens is the American English equivalent.

lift club 'car pool'. The definiens is the American English equivalent.

make a joke 'tell a joke'. American English distinguishes tell a joke 'relate a funny story' and make a joke 'to joke, talk in a jocular way, behave in a jocular way'.

Maria 'maid'. Informal count noun, probably offensive. E.g., "He treats his wife as if she were a Maria!"

matriculate 'pass [a student] in the Matriculation Examination'. E.g., "Do you think a matriculated Transvaler has the same chances as any other matriculated South African?"

O.D.F. 'old Durban family'. Informal letterword. E.g., "They're of an O.D.F."

paper As in "a small paper of dagga," which is the compilers' definition of kaartiie. In American English, paper is so used too (to refer to a small packet of any narcotic). 
pass Transitive verb. E.g., "Please pass Isaac until seven o'clock tonight." Based on the noun pass sense 2 (q.v.). With the abolition of the passbook or reference book system, this usage is now historical.

pay packet 'pay envelope'. The definiens is the American English equivalent.

run around 'behave licentiously, esp. engaging in promiscuous sex'. Informal. Also in American English.

sister 'nurse'. Informal. E.g., "I asked the sister how the patient was feeling."

sit As in "We sit in Africa and we are not Africans" (citation s.v. European). This may be a largely South African usage (it is also found in Hebrew-influenced English; cf. Heb. yashav 'to sit; to live, reside, dwell').

stick fight 'men's game, played according to certain rules, in which each fighter holds a straight stick (called a kleilat or kleilatjie) in the middle as a shield (a rag tied around his hand) and goes at his opponent with a knobkerrie, trying to hit him as hard as he can'. The citation kleilat / kleilatjie alludes to this game: "...amused themselves by fighting with sticks...."

thick as hell 'hard-nosed, conscientious, completely reliable'. Informal. E.g., "She's my best worker — thick as hell."

through The citation s.v. rooikeurtjie says that this plant "was declared a weed through the Republic...." If through is not a misprint for throughout, it is worthy of note.

to As in "the biblical foundations to apartheid" (see the first citation at NGK). In American English, foundation takes of.

two-two '.22-caliber rifle'. Informal.

vigneron 'vintner'. Often used by vintners in the Franschhoek Valley as a selfdesignation (many of them descend from French Huguenots, hence this French-origin word).

vover 'coin worth six pence'. Jewish South African English. Like general-SouthAfrican-English zack 'idem', this word became obsolete with the introduction of decimal currency. The etymology of vover is given in Jewish Language Review 3: 318-319.

vroedvrou 'midwife'. Used mostly of Colored midwives. 
Well over the fast! Greeting used by Jews to one another before any fast (the only fast which South African Jews in any significant numbers now observe being that of the Day of Atonement). The etymology and other information are given in Jewish Linguistic Studies 2: 450-451.

\section{Definitions}

Some of the definitions or background information in the fourth edition can be made more precise.

bekslaner hek The definition given is 'a type of farm gate'. Details would be useful. See section 13.

Black Sash The official name of the organization, Women's Defense of the Constitution League, could be added.

bliksem Entered as a noun and interjection, this word is also a verb (see the third citation).

boer- and boere- / Boere- This compound-forming element should be defined more uniformly in the etymologies (compare, for example, the etymologies of boer goat and boerperd or boereliedjie and boeremusiek).

bra This word is given two separate entries, each with a superscript number, thus implying that each is of a different origin. Is this not the same word with two meanings? See koelie in section 6.

childminder It might be useful to compare the South African sense of this word with the British one.

com-tsotsi The definition given is 'gangster calling himself a "comrade"'. Since a definiens should normally be substitutable for its definiendum, the definition should be 'comrade', with the rest of the material ("gangster's self-designation") going into the paragraph reserved for "information or comment not strictly part of a definition" (p. xxix).

concentration camp The definition given is 'first used of those camps in which Boer women and children were detained in the S. Afr. War of 1899-1902'. Because many people think that this lexeme was first applied to Nazi camps, the compilers are right in making their point ('first used...'), but it belongs with "information or comment not strictly part of a definition" (p. xxix). Hence the definition should begin 'a camp in which...'. Whether concentration camp in reference to the Nazi camps is a continuation of the South African English 
usage, a translation of German Konzentrationslager, or both remains to be seen.

Day of Goodwill The definition (merely '26th December') should be expanded to explain why the day is so called.

ewe The first four words of the definition should be deleted as superfluous: 'in SA used of the female goat and antelope...'.

halfkoord Since no definition is provided, the reader is presumably to infer it from the etymology, which is "prob. corruption of albacore." Yet even if that etymology is, grosso modo, correct, ${ }^{5}$ the reader is owed an explicit definition, inasmuch as etymon and reflex need not have the same meaning, hence the reader should assume nothing. The spelling of the word suggests that Afrikaans may be its immediate source (though see note 21 on the need to be guided by more than spelling).

heemraad See comments at smous in section 3.

kaapse draai It's impossible to determine the meaning of this lexeme from the information provided.

$k^{\prime}$ daar Since Afrikaans has been used mostly in South Africa, the fact that this word is of Afrikaans origin suggests that, at least when first used, it was in mockery of specifically South African tourists (or, more specifically, Afrikaansspeaking South African tourists), whose wide-eyed exclamation, "Kyk daar!," is echoed here, i.e., non-South-African tourists would presumably not be speaking Afrikaans, hence not so called. As far as I can determine, $k^{\prime} d a a r$ is still applied only to South Africans. Also, this entry should have a cross-reference to $k y k$, ky-daar.

koeksister 'a traditional Cape confection poss. of Malay origin: a deep-fried twisted or plaited doughnut immediately dipped in syrup (also vulg.) a Lesbian'. The compilers presumably mean lesbian 'female homosexual' and not Lesbian 'native or resident of Lesbos'. In several of the world's languages, names of foods (especially baked or otherwise cooked ones) are also slangisms referring to women (or, more specifically, to the female genitals): Mexican Spanish tortillera 'lesbian' (lit. 'tortilla maker'), Jewish South African English kugl (s.v. "kugel" in this dictionary), American English slang jelly-roll 'vulva; vagina', English slang tart, and Eastern Yiddish slang knish and kugl $[=$ the key to the explanation of Jewish South African English kugl 'a young girl of the wealthier class...'], and pirge (all three derived from food terms and all three referring to the female genitals [Gold to appear]).

Nusas Part of the definition reads '...and disbanded in 1991'. It would be good 
to say why.

If off is labeled "Black English," the definition need not begin with the words "used by black speakers sig."

pack in This verb is transitive, but the definition given, 'to pack clothing, books etc.', is intransitive. Brackets will make it transitive: 'to pack [clothing, books, etc.]'. Cf. forget in section 4, where the definition, quoted verbatim from this dictionary, illustrates the correct way of setting off typical complements of a verb when defining it (though brackets are better than parentheses because the latter should be used to set off optional parts of the definition). See also pack in in section 4 .

petrol jockey The citation is not enough to serve as a definition.

plat The definition given is 'vulgar, unrefined usu. of or pertaining to accent or other linguistic manifestation: cf. Plat Deutsch'. Plattdeutsch (sic recte) is a neutral word and not, as the compilers believe, a pejorative one: Hochdeutsch 'High German' and Plattdeutsch 'Low German' are so named because the former is spoken around the upper reaches of the Rhine (the "highlands") and the latter around its lower reaches (the "lowlands"). Reference is thus to geography and not to basilect and acrolect. 6

ramkietjie The ethnic status of the instrument should be specified (from the spelling one assumes it to be Afrikaner).

slave bell The definition given is 'a bell set usu. in a tall, whitewashed arch for summoning slaves esp. on Cape farms'. Slavery having been abolished in South Africa, one infers from the definition that the bell is no longer rung (i.e., that slave bell is a time-bound word [see smous below]), yet in some places it is still rung in the mornings to summon the farmhands.

smous The definition begins 'formerly an itinerant pedlar...', but the first word is actually a usage label and should therefore not be part of the definition (see com-tsotsi in section 3). The compilers do have a label for such items, hist., which should appear here as a usage label in place of "formerly" in the definition.? Such items are called time-bound usages (or, more specifically, time-bound lexemes, time-bound words, time-bound meanings, etc.) or historicisms. Since heemraad is labeled "historical," its definition contains a superfluous adverb: 'a district council formerly assisting the landdrost...'.$^{8}$

tickey drive The definition given is 'a function similar to a tickey aand, tickey evening'. An explanation of how they differ could be added. 
toyi-toyi It might be added that the dance is usual at funerals too, especially of those who have died as a result of political or social turmoil.

turned The definition given is 'used of guerilla fighter induced to join a counter-insurgency unit'. As at cum-tsotsi, too much has been put into the definiens. Read 'induced to join a counter-insurgency unit', with "applied to a guerilla fighter" (or some similar wording) to go into the paragraph reserved for "information or comment not strictly part of a definition" (p. xxix). Also, since lexemes should be listed in their base form, the entry head should be turn, with an appropriate adjustment in the definition ('to be induced to...').

Transvaler, Transvaaler The definition given is 'an inhabitant of the Transvaal whether by birth or inclination'. For two reasons, a better one would be 'native or resident of the Transvaal' (someone born in the Transvaal but now not living there is still a Transvaaler, i.e., by birth; and someone, whether or not born there, may be living in the Transvaal for a reason other than inclination).

volk The definition given is 'labourers, usu. farmhands'. Should not 'usually Coloured' be added?

\section{Identical or similar usages in other varieties of English}

An excellent feature of this dictionary is its recording of similar, analogous, or otherwise related usages in non-South-African varieties of English. Some American English equivalents are offered in section 3 and here are more:

babbalaas / babbalas The compilers write "cf. U.S. katzenjammer." This word has been obsolete for several decades, the current American English word being hangover.

Big House 'Pretoria Central Prison'. Cf. American English the big house '[any] state or federal prison'. Is the definite article not needed in the South African lexeme too?

bilingual 'in SA, proficient in both English and Afrikaans (not in any two languages)'. Cf. Canadian English bilingual, bilingualism and Canadian French bilingue, bilinguisme, which refer specifically to French and English. In New York City, bilingual not infrequently refers specifically to English and Spanish.9

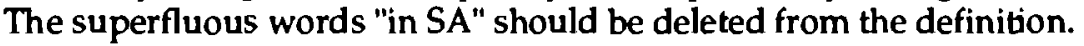

a bread In Ashkenazic English too (a literal translation of Yiddish a broyt 'a loaf of bread'). 
by 'used sig. either "beside" (alongside) or "with" or "at....". In American English too, e.g. "We went by their house Monday night" (not only in the sense of 'walked past' or 'drove past' but also 'went to [and entered]', e.g., "Come by at around six o'clock and we'll have dinner together"). On the other hand, in contexts like "I'll be by my grandmother's" and "By her everything is so clean" (i.e., 'I'll be at my grandmother's house' and 'In her house everything is so clean'), the word is ethnolectal (e.g., Ashkenazic English, as a translation of Yiddish $b a$ 'at, in'). The words "used sig. either" are superfluous.

can't complain 'response to How goes it? How are you? sig. "All right'". In American English too (cf. earlier remarks in Gold 1986a: 139). The compilers' etymology of the South African usage is "probably from Afrikaans kannie kla nie." Do the Afrikaans and American English usages have a common source (viz. Dutch)?

By comparing American English and South African English, the researcher is alerted to possible items of hitherto unnoticed Dutch origin (European Dutch > New Netherland Dutch > American English; European Dutch > Afrikaans > South African English). A clearcut example is cookie, which is found (with slightly different meanings) in American English (< New Netherland Dutch < European Dutch), South African English (< Afrikaans < European Dutch), and Scots English (< European Dutch).

When comparing American English and South African English for evidence of possible Dutch influence, one must proceed carefully for two reasons. First, because of the possibility of chance convergence (the identical or similar items found in these two varieties of English need not be due to a common Dutch origin or they may be of Dutch origin in one of these varieties but not in the other). Second, because the Afrikaans items presumably linking South African English and Dutch could actually be of South African English origin (i.e., instead of South African English < Afrikaans < Dutch, the correct etymological chain could be Afrikaans < South African English, with Dutch being irrelevant Isee note 21 for an example (though without reference to Dutch) of how it is not always clear whether the etymology of an item is South African English < Afrikaans or Afrikaans < South African English]). Hence the question would be, rather, whether the South African English and American English usages have a common source not in Dutch but in some other language (first and foremost, one thinks of British English). Indeed, the compilers' use of the word probably indicates that they are not absolutely certain in which direction influence has gone. Cf. forget, kaalgat; make; Nooitverwacht; pit; time in; wait on; want to, doesn't / don't; pantsula; saddle up; stand; and waai (all in section 4) and note 42 for more on possible Dutch influence. In like manner, a comparison of American English and South African English alerts the researcher to the possible African origin of certain items (see family jewwels in section 4). 
cheeky In American English too. Based on cheek 'impudence'.

donga This South African English word has entered Australian English (Gold 1989a: 242-243).

-ed "Dropping of the alveolar suffix -ed is not confined to SAE, but is very prevalent in SA, e.g., barb wire, three bedroom house, pickle onion, old fashion home, long sleeve shirt, etc." (ss.vv. omissions and klappertert more examples are given [pre-pack sweets and pickle fish], to which curry bunny / curried bunny and finished and klaar / finish and klaar may be added). In contemporary American English, three-bedroom house is usual; barb wire is usual informally and barbed wire formally; long-sleeve shirt is usual in speech (because of the difficult-to-pronounce consonant cluster in long-sleeved shirt [cf. remarks at Omissions in section 4]); and old-fashion home, pickle onion and pre-pack sweets sound basilectal (I have no opinion on curry bunny / curried bunny, which I do not know).

forget. 'to leave behind (some concrete object, book, jersey etc.)'. The compilers label this sense substandard and attribute it to the influence of Afrikaans. It is, however, universal and standard in English (the Oxford English Dictionary, second edition, writes 'to omit to take, leave behind inadvertently', with citations from before 1300, 1535, 1596, 1766, and 1860'). Here is a recent citation from American English: "As Mrs. Lipstein spoke, she noticed that a stranger had forgotten her sunglasses on the counter" (Diana Jean Schemo in The New York Times of 6 May 1992, p. B3). Hence, at most, Afrikaans reinforces this usage. The word 'unintentionally' should be added to the compilers' definition. Earlier comments in Gold 1986a: 138 and 1989a: 252 are now outdated.

family 'relations in general as opposed to one's immediately family'. In American English too, e.g., "I have family in South America - fifth and sixth cousins." Cf. people in section 4.

family jewels 'male genitals'. In American English too, where this sense MAY have originally been Black English only (Major 1970 lists it).10 Is it therefore possible that the American and South African English usages have a common origin in some African language? (Cf. can't complain, kwaai and man in section 4). Chapman (cf. Gold 1990b) defines the American English lexeme as 'the testicles', but that may be an error for 'male genitals'.

hey '...a means of attracting attention or response', as in 'What do you think of that - hey?" In Canadian English too, where the $h$ is not pronounced.

just now 'in a little while; often with reference to the immediate future as in "I'm coming just now"; occasionally also to the immediate past, as in "He was here just now"; but not the immediate present, as in standard "We have none 
in stock just now"'. American English does not have the first usage; it has the second one; and in the third sense, it has right now (e.g., "We have none in stock right now, but we should be getting some in next week").

kaalgat The compilers note American English bare-assed. Might both usages have a common origin in Dutch? Cf. can't complain in section 4.

kangaroo court The compilers' treatment of this lexeme suggests they think it came to South Africa from Australia, but they may have been misled by the fact that the kangaroo is associated with the latter country. As far as is known, kangaroo court arose in American English (the justice dispensed by such a court is said to progress, like the animal, "by leaps and bounds"; alliteration also had something to do with the choice of the word kangaroo). Is the lexeme used in Australia? If not, it definitely reached South Africa from the United States. If it is used in Australia (where it would presumably be of American English origin), the South African usage could be of American, Australian, or both origins. The earliest American citation now available is from 1853.

\section{klinker Cf. general-English clinker, in various senses.}

kwaai The compilers note: "more recently a general term of approval." The ultimate origin of this word is Dutch kwaad 'bad'. In Black American English, bad shows the same semantic development from 'bad' to, additionally, 'good'. The sentence "Man, that music is really bad!," for example, is ambiguous. If I am not mistaken, this Black American English usage has been ascribed to the influence of certain languages of western Africa. The South African usage may thus be of African origin. Cf. can't complain, kwaai, and man in section 4.

make 'do, sig. prepare, cook; of a raw material as opposed to a dish, as in "I'm making chicken, making rice, making sweet potatoes"'. In American English too. Since the compilers say that this usage is "possibly a transliteration of Afrikaans maak 'do'," might Dutch be the common source of both the American and South African usages? Cf. can't complain in section 4.

makgotla This entry could be cross-referred to kangaroo court.

man 'colloq. interj. Used for emphasis [e.g., "It's working perfectly, Man! I mus' say I like these old stoves"]; colloq. a mode of address regardless of the sex of the person addressed and often redundant [e.g., "I'm not deaf, man"]'. In American English, this was originally a Black usage, but is now an ethnically almost unmarked slangism. The fact that it began among Blacks in American English and is widespread in Caribbean English suggests a possible African origin, in which case, the South African English usage might likewise be a 
translation from some African language. Cf. can't complain, family jewels, and kwaai in section 4.

Nooitverwacht (a place name given s.v. verwag). Neversink is the name of a place in New York State whose meaning (presumably 'never sink') is reminiscent of the Dutch and Afrikaans place names in South Africa beginning with 'never'. Could Neversink, therefore, have earlier had a Dutch name, of which its present name is a translation? A comparison of Dutch and Afrikaans toponymy in South Africa and Dutch toponymy in the United States might be revealing (see can't complain in section 4).

Omissions: Some of the phenomena reported in this entry have analogs elsewhere in the English-speaking world:

[a] Absence of are seems to be found in several varieties of Black English.

[b] "We came back from holiday last week" is analogous to standard American English "We came back from vacation last week" (the only way the supposed omission can be avoided in American English is by using a possessive adjective: "...from our vacation....").

[c] "play guitar," "play piano," "play concertina" are acceptable in informal American English.

[d] automatic 'car with automatic shift; automatic washing machine' is acceptable in informal American English.

[e] 'Viv explains me the assignment...." In Ashkenazic English too, as a result of Yiddish influence (cf. Yid. zi git mir tsu farshteyn dem fargeb 'She explains the assignment to me').

[f] "It is no use moralising and lecturing them." American English distinguishes lecture to (e.g., "When I was a teacher, I would have to lecture to about seventy students a week," i.e., 'teach a class to') and lecture 'to rebuke or scold at length' (as in, "Stop lecturing me!"). I suspect that South African English makes the same distinction, but the compilers have mistaken lecture for lecture to. If so, the distinction is useful and not to be condemned or even noted in a supplementary dictionary.

[g] "Be careful your feet." In Ashkenazic English too, as a result of Yiddish influence (cf. Yid. hits enk di fis! 'Watch your step!'). 
[h] "Two boxes matches." In Ashkenazic English too, as a result of Yiddish influence (cf. Yid. tsvey peklekh shvebelekh 'two boxes of matches').

[i] "Plenty wine." In Tristan da Cunha English (Gold 1990b: 154) and informal American English too. In American English, this usage is often ascribed to the influence of Yiddish, which is, however, only one of its sources (Yid. e.g., genug vayn). In general, students of South African English might have a look at Tristan da Cunha English, for both of them share certain features.

[j] "We beat...the Women's Hockey Club...." This is given as an example of the omission of possessive 's. Hockey club is standard and universal in American English, where "hockey's club" is nonexistent, at least today (the compilers indeed note that possessive 's is "also dropped in U.S. barber shop, florist shop, etc."). Omission is frequent when a difficult-to-pronounce consonant cluster might otherwise be the result (try pronouncing "florist's shop" with no omissions). Cf. also South African English bachelors "quarters / bachelors quarters and remarks at -ed in section 4 on consonant clusters.

[k] Omission of $-s$ and -es in the third-person singular of present-tense verbs, e.g., "...the wife play." In the Black English of many places too.

on The compilers label use of this preposition in sentences like "For details contact Mr Wessels on 94 2632" as nonstandard." It is acceptable in British English and Australian English, where it is not of Afrikaans origin, hence one wonders whether they are right in attributing it to Afrikaans influence on South African English. Perhaps it is of both origins (cf. their remark that "the relative weightings of Afrikaans and of 'internal' English dialectal influences on SAE are by no means settled," p. xvii12). American English has at ("Call me at....").

on Likewise labeled nonstandard is use of this preposition in the context "On the preceding weekend...." It sounds acceptable to an American ear, though pompous ("the weekend before" is better).

pack in [Defined in section 3]. In Ashkenazic English too, as a result of Yiddish influence (Yid. aynpakn), e.g., "Did you pack in the slippers yet?"

people 'relations in general as opposed to one's immediate family'. A similar usage is found in American English, where people can mean 'one's family 
(including extended family, living or dead)', e.g., "My people are from Transylvania" or "Her people came over here generations ago." Cf. family in section 4. To my ear, people, but not family, sounds a tad basilectal.

pharmacy American English pharmacy (at least slightly formal now in the sense of 'drug store') and drug store show the same semantic development as pharmacy in South African English. Has American English influenced South African English in this regard? Note that in a restricted sense ('area or part of a drug store in which prescription drugs, etc. are dispensed') pharmacy is not formal in American English.

pit 'pip or stone of fruit or vegetable'. In American English too, where this usage is of New Netherland Dutch origin, hence a clear instance of American and South African English convergence due to the influence of Dutch in one instance and Afrikaans in the other (cf. can't complain in section 4). Earlier remarks in Gold 1986a: 139.

play white The Black American English equivalent is the intransitive verb pass, e.g., "She's so light she could easily pass" (shortened from pass for a White person, pass for a White, and pass for White).

poes 'the female genitals'. Cf. American English pussy in the same sense..$^{13}$ It is probably a coincidence that in at least two other languages equivalents begin with /p/: Hebrew pot and Yiddish pirge.

rainmaker The word is used in American English too, originally in reference to Native Americans, now with other meanings too.

robot "Cf. Brit. and U.S. robot 'automaton'." Is not robot 'automaton' universal in English?

saddle up 'to saddle [a horse]'. The etymology given is "Du. opzadeln." In American English too, where usage is as follows: with an object, the preposition is frequent (usual?) in informal registers (e.g., "I saddled up the horse") and absent in formal registers (e.g., "I saddled the horse"); without an object, the preposition is obligatory ("I saddled up and rode off"). Presumably an instance of convergence due to the influence of Dutch (cf. can't complain in section 4). How would non-Dutch-influenced English use the verb absolutely, i.e., with no object? "I saddled" does not sound idiomatic.

Spoilers In American English too, the Spoilers has been used as a gang name.

stove The American English equivalent which the compilers give is range. However, stove is used in American English too, in exactly the same sense 
which this dictionary shows for the word in South African English. The distribution of these two words in American English differs spatially, chronologically, and possibly socially:

That's him 'used as an affirmative or agreement equiv. of "Yes" or "That's it," when the object referred to is nonanimate' (e.g., "Is this what you're looking for? ... Ja, Henk, that's him"). Possible in American English too (basilectal?).

tickey evening '...in which entrance for an event or game was formerly a tickey (threepence), now five, ten, or more cents, though the name is still in use'. Cf. American English five-and-dime / five-and-ten as the names for a kind of store in which all merchandise once cost only five or ten cents, but now nothing can be bought for those prices, though the names remain.

time, in As in "I completed these displays in three years' time." This usage is found in American English too (from New Netherland Dutch?), though it is bad style (cf. can't complain in section 4).

up "Time's up" is mentioned here as British English. It is used in American English too.

waai In "I must waai" and "Ek moet waai," i.e., 'I must go' (literally 'I must blow'). American English has blow 'to leave, depart' (e.g., "I'm blowing - I got a job in South America"), usually as a transitive verb (e.g., "to blow town"). Is Dutch the common source? Cf. can't complain in section 4. The Canadian English expression given at waai, hit the trail, is a synonym based on a different image, hence should be deleted.

wait on 'wait for'. In American English too. The compilers label this South African English usage as substandard, etymologizing it as being a translation of Afrikaans wag op. The Afrikaans usage is of Dutch origin (wachten op, opwachten). Is the American English one too? Cf. can't complain in section 4.

want to, doesn't / don't With an inanimate subject (as in "This door doesn't want to open"). In American English too, though usually only in extreme exasperation or desperation (is Dutch willen so used?). The compilers label this usage as substandard. In American English, it is merely informal. Cf. the opposite development of English will from a full verb meaning 'to be willing, desire' to an auxiliary indicating future time, but even today with echoes of its former use, e.g., "The door will not open," i.e., "The door does not "want" to open' (cf. can't complain in section 4).

who-all The compilers give Southeastern American English you-all as analogous, but it is irrelevant since the purpose of all in you-all is to mark the plural 
overtly (which is not the function of all in South African English who-all).

\section{Identical or similar usages in other languages}

butterbread 'bread and butter'. Cf. Ger. Butterbrot 'slice of bread and butter' and Butterbrote 'bread and butter'. Earlier comments in Gold 1989a: 251.

I' $m$ telling you 'used for emphasis to increase the impact of the statement made or the event related'. So too in Israeli Hebrew (ani omer lecha!) and Ashkenazic English (I am telling you!), both usages being translations of Yiddish ikh zog dir!. Earlier comments in Gold 1986a: 141.

laager mentality. Cf. American (if not general) English bunker mentality and, in reference to Jewish Israelis, Massada complex.

person as a pseudo-pronoun (as in "There is also severe scarring to his leg which is now an ugly sight and offends a person's aesthetic sensibilities"), which the compilers label as substandard and etymologize as "trans. Afk. " $n$ mens." This usage is found in informal American English and in at least some varieties of Judezmo too, e.g., "aki la prisone s'pwedi afugar dil fumu" 'A person here can choke to death from the smoke'.14 This usage carries a nuance which words like somebody, someone, one, you, etc. do not have, hence it is not to be condemned: person stresses human dignity and the need to respect it. Contrast, for example, "It offends one's sense of dignity" and "It offends a person's sense of dignity." Indeed, all of the compilers' examples allude to respect or dignity: "But you make a fool of a person," "[It] offends a person's aesthetic sensibilities," and "A person can get very lonely living by herself." Hence they may have missed a nuance and thereby condemned a good usage unjustifiedly.

somewhere on the Border (s.v. basics). The Israeli Hebrew analog is e-sham baarets 'somewhere in Israel' (people serving in the Israeli military are forbidden to reveal their location, this being the cliche used to avoid specification; likewise, radio and television reporters broadcasting from any military installation say that they are 'somewhere in Israel').

veld remedy Among those listed are "cobwebs to stop bleeding." My mother, who was born in Łagów, Poland, in 1912 and left the town in 1927, recalls that Jews in her town would put cobwebs on an open wound to prevent infection.

\section{Etymologies}

The compilers use the label 'transliteration' "where an Afrikaans word or 
phrase is rendered into an approximate English sound pattern to convey the meaning of (or translating) the original: e.g., cotch (Afrikaans kots, puke); greet (Afrikaans groet, to take leave of, say goodbye); ride (Afrikaans ry, to convey) etc." (p. $\mathbf{x x x}$ ). Terminological innovation is necessary if no term exists or the existing term or terms are inadequate. Yet English has respelling (e.g., for cotch) and translation (e.g., for greet), with transliteration referring to the symbol-forsymbol replacement used when converting from one spelling system to another (e.g., <'wndz> is a transliteration of Yiddish undz 'our; we'). Why the compilers have chosen to ignore the established meaning of transliteration and use it in two unnecessary senses (which, moreover, do not allow them to distinguish respelling and translation) is unclear.

A more nuanced, traditional terminology would have also alerted the compilers to certain problems of etymology, which their blanket term "transliteration" masks. For example, the exact relationship between South African English ride and Afrikaans etymon ry 'to ride'. It is not an instance of respelling, but a simple case of translation (unless the etymon is not Afrikaans $r y$ but the stem of Dutch rijden 'to ride', whose /d/ would account for that of ride, in which case it would be a respelling). 15

Here are some suggestions for improving the etymologies:

ag The etymology given is "Afk. fr. Du. ach as in Ger." Is it right to expect the reader to know German? Cf. section 10 on presupposed knowledge of another kind.

bakkie Two numbered definitions are given for this word. An etymology appears only at the end of the second one. Were the etymology at the very end of the entry, we would assume it to apply to the word as a whole. It is given, however, before the citation for the second definition, hence it presumably applies to bakkie only in its second sense. In the assumption that the etymology is not misplaced (see section 12), what is the origin of bakkie in its first sense, 'a light motor truck with a cabin and open back...? An explanation popular in South Africa is that in this sense the English word derives from Afrikaans bakkie and that the latter word is from English buggy. ${ }^{16}$ Is that correct?

balie 'tub or vat... The etymology given is "Afk. balie poss. cogn. vb. bail, or barrel." Is Scots English bally 'milk pail' (recorded in Wright's English Dialect Dictionary and in the Scottish National Dictionary) not relevant? Distantly related to these words is Eastern Yiddish balye 'washtub', which is from Polish balja 'idem', which is from German Balje 'idem', which can presumably be linked to the Scots, South African English, and Afrikaans words in some way.

bloubaadjie The etymology mentions rok, but it is not clear how this word enters the picture (see note 33 ). 
bolo 'a forequarter cut of beef' (with this citation from the Sunday Times of 6 February 1972: "Usually you'll pay a little less...than for hindquarter cuts. Bolo is a forequarter cut. It tastes like topside, and is cooked the same"). "Etymology unknown." See Jewish Language Review 7: 452 and 552-555; and Jewish Linguistic Studies 2: 484. South African English red bolus 'red colouring matter orig. used in certain traditional sweetmeats' ("etymology unknown") may be related.

buppie From American English, where it was coined.

by-and-by The etymology given is "Nguni mbayi-mbayi 'cannon"' and the citation implies that the Nguni word is from English by-and-by. Is the citation correct?

bywoner The etymology given is "Afk. by 'with, at' + woner 'dweller'...," but that wrongly implies a pseudo-Afrikaansism in English, i.e., that bywoner was coined in English with raw material from Afrikaans. Read < Afrikaans bywoner $=$ Afk. by 'with, at' + Afk. woner 'dweller' (unless Dutch has "?bijwoner in a suitable sense, in which case the Afrikaans word was not formed in Afrikaans). This error (of giving the wrong language or wrong variety of a language as the venue for the coinage of a word) is found numerous times in this dictionary (see coon, klawerjas, piepiejoller, rixdollar, ting-tinkie, tot siens, and Turnhalle in section 6 and poenskop / poeskop in section 12, which are only a few of the examples that could be cited).

\section{Cockney Is this not a pun on general-English cockney?}

coolie The etymology given is "prob. fr. Tamil, Urdu, Telegu, etc. kuli labourer, also Chinese." A more probable etymology is < British English < Indian English $<$ one or more languages of India. The meaning or relevance of "also Chinese" is unclear. See also koelie below.

coon The etymology given, "fr. raccoon U.S.," implies it was in South African English that American English raccoon was shortened. Coon, however, already existed in American English (indeed, the compilers cite it), hence the correct etymology is "< American English coon (= shortening of raccoon)."1"

Durbs, Joeys, Tassies; Wits, Tuks; Afriks The words separated by commas have the same |s| morpheme (and should therefore be cross-referred). Is this in fact a single morpheme shared by all six words? Is the use of $\{\mathrm{s}\}$ in English to form slangy clippings limited to South African English? Can more names be added to this list, which consists of three names of cities, two of schools, and one of a school subject?" The first, third, and sixth words are labeled "colloquial" and the second "slang." The other two are unlabeled. Do not all belong to the same 
dust devil "Etymology unknown." Need an etymology be sought for a metaphor?

fieta The etymology given, "in pl. form, place name Fietas...," could be made clearer: "back-formed from fietas [interpreted as a plural], from Fietas...." In amalaita, we see the reverse phenomenon: some English-speakers have reinterpreted this word as a singular, hence a new plural has emerged, amalaitas. South Africans will probably understand why Fietas has been so used, but for the benefit of others, an explanation would be good.

government sugar The etymology given is "poss. orig. fr. 'Government subsidized'." Why not by analogy with government flour (where the reason for the word government is clear)? That is, once government flour acquired the connotation of 'cheaper flour' or 'less good flour', government could be applied to other cheaper or less good commodities, i.e., this word now effectively means 'cheaper; less good' (but only when modifying flour and sugar).

syppo The only etymological information offered is "not equiv. World War II abbr. for Egyptian", which presumably means 'not a semantic extension of slang syppo "Egyptian," used in World War 2' (it is not an "abbreviation"19). Negative etymologies are good (see note 40 ), but a positive one should be given too, if available. How about gyp + slang ending -0 ?

hesh girl < hash girl and pellie < pal show the same vowel change (due to Afrikaans influence?). "Presumably" may be deleted in the etymology of the latter word, it being certain that pellie is derived from Eng. pal + affective suffix -ie.

Ikey The definition and etymology given are 'a student or alumnus of the University of Cape Town: esp. a member of one of its sports teams' "fr. name Isaac." Is it known why this name was chosen?

Jim Fish The etymology given is "cf. U.S. Jim Crow. II Prob. fr. 'Jim Fish' a character who was always getting into trouble in 1940s' training films for miners." Research, if possible, is needed to determine whether the South African and American usages are related. "Jim Crow" was the name of a song sung by Thomas Rice (1808-1860) in an American minstrel show, hence the American usage.

kak The etymology given is "Afk. fr. Du. kak 'excrement' fr. Lat. cacare 'to defaecate'." Latin is not the immediate source of the Dutch word. 
klawerjas The etymology given, "Afk. fr. Du. klaver 'club' + Du. jas 'knave of trumps'," implies that the compound was first formed in Afrikaans. However, it already existed in Dutch (as the second citation shows ("...the Dutch call it 'Klaviarsz'..."), hence the correct etymology is "< Afk. klawerjas < Dutch klaverjas = Dutch klaver + Dutch jas." Note the curious spelling ("-rsz") in the citation, which is similar to kalabriasz, used by Damon Runyon. 20

koelie This word is given two separate entries, each with a superscript number, but they are the same word, with two meanings. Instead of the etymologies proposed, this one is more probable: "< Afk. koelie < South African English coolie < British English coolie < Indian English < one or more languages of India." See also bra in section 3 and coolie in section 6.

lend The etymology given is "trans. or 'translit.' Afk. leen...." This is a translation.

maas 'thick, naturally soured milk... cf. Persian māst, sour milk or cream'. The etymology given is "Ngu. amasi 'sour milk'." Since the spelling maas is Afrikaans (it would presumably not occur to an English-speaker who does not know Afrikaans to double the $a$ ), the English word is probably of immediate Afrikaans origin (hence English < Afrikaans < Nguni). ${ }^{21}$ Mention of Persian in the definition (which should have been made in the etymology) suggests a possible wider connection (cf., however, the caution in Gold 1989a: 255 on Persian and South African English). Eastern Yiddish mashlinke 'buttermilk' (with several phonological variants) is from Polish maślanka. Can the latter eventually be linked to the Persian word?

maffick The etymology should say that this word was coined in London, England, where the first celebration marking the end of the siege of Mafeking took place. Although the word was thus not coined in South Africa, it takes its rightful place in this dictionary because of its historical relevance.

mali Can the etymology ("Nguni imali 'money"') be taken back further? Perhaps the Nguni word is derived from English money (on variation between / $\mathrm{n}$ / and /1/ in many languages, see Jewish Language Review 7: 455-456 and Jewish Linguistic Studies 2: 484-485).

monk 'angler-(fish)'. "Etymology unknown." The fish is so called because of its remote, sea-bottom habitat. The word is so used in American English too, where it is synonymous with monkfish.

monkeys' wedding 'simultaneous rain and sunshine poss. so called from the incongruous comb. see also jakkalstrou cf. Jam. Eng. devil rain and Du. Kermis in 
de Hel. [prob. trans. Zu. (for this phenomenon) umshado wezinkawu a wedding for monkeys]'. See Gold 1981a and 1984a for many more analogs.

morming gown 'a dressing gown'. "Etymology unknown." Is an etymology necessary for a transparent compound (the gown usually being worn in the morning, before one has dressed)?

Muldergate The etymology ("Mulder name + gate...") needs to be fleshed out, with a reference to Connie Mulder (at the time South Africa's Minister of Information), etc.

nonna The etymology given is "prob. fr. Malay nonya respectful form of address to a woman of the upper class: poss. fr. Port. dona, lady, fr. Lat. domina, mistress." It is unclear what the colon means. Does it begin a new possibility (i.e., South African English nonna is probably from Malay, but, if that etymology is wrong, the word is possibly from Portuguese)? Or does it begin an additional possibility (the word is probably from Malay and may, in addition, be from Portuguese, i.e., it could have two immediate etymons)? Or, is the Malay word possibly from Portuguese? At nooi, the etymology reads: "Afk. prob. fr. Mal. nyonyah / njonjah rel. Port. dona fr. Lat. domina, mistress." Here, on the other hand, Malay and Portuguese are put in a definite relationship (it must be Malay < Portuguese), hence this etymology is not in harmony with that proposed for nonna, whatever the latter may be.

nylon 'sl. term for a woman'. "Etymology unknown." This is an instance of metonymy. Cf. older English slang skirt 'girl, woman'.

pantsula No etymology is given. The word is presumably derived from one or more African languages and in the latter it is from English pants + the native suffix -ula. It may be noted that South African English and American English are alike in using pants to mean 'trousers' (whereas in British English the word means 'underpants'). Trousers is older American English (still used by some elderly people in the 1950 s and now probably obsolete). Might the influence of Dutch pantalon (or its Afrikaans reflex with respect to South Africa) explain pants 'trousers' in the United States and South Africa? Cf. can't complain in section 4.

Peruvian The etymology of this word is discussed in Jewish Language Review 3: 319 and 7:531-532 and Jewish Linguistic Studies 2: 455-456.

piccanin Cf. American English picaninny, Jamaican English pickney, and West African English pickin, the meanings, connotations, and currency of which vary from place to place. 
piepiejoller The etymology given is "piepie, Afk. child's term for penis + joller." The occurrence of initial / $\mathrm{p} /$ in not a few words meaning 'penis' or 'urination' in several languages of Europe suggests that they may have a common origin. First we have a family of forms consisting of reflexes of Indo-European "-put 'a swelling': Latin 'putos 'penis' (whence Latin -putium, which seems to survive only in Latin praeputium 'prepuce'), Belorussian potka 'penis', and Yiddish pots 'penis' (cf. also Lithuanian pusti 'to swell', from the same Indo-European root). Whether Afrikaans piel 'penis' is part of this family of words remains to be seen. Then we have English penis (and related words in other languages), pecker, and prick (each of a different origin, but noteworthy because of $/ \mathrm{p} /$ ). As for 'to urinate', we have English piss, English pee (also duplicated: peepee), and Yiddish pishn.

piet-my-vrou The etymology given is "fr. call." Yes, but the word has a literal meaning, which should be given.

pirate taxi The word "probably" may be removed from the etymology since the compilers' explanation is correct.

plus-minus The etymology given is "Afk. fr. Lat. plus-minus 'approximately'." It is improbable for three reasons: Afrikaans is unlikely to have borrowed from Latin; no such Latin lexeme exists; and if Dutch has a possible etymon, Dutch influence on Afrikaans is the first possibility to consider. Indeed, Dutch has plus-minus 'approximately'. Hence: < Afk. < Dutch < Latin plus 'plus' + Latin minus 'minus'.

rixdollar The etymology given, "anglicization of Dutch rijks + daalder," implies that an English-speaker took two Dutch words and used them to coin an English compound. Rixdollar, which was coined in English, is actually a partial respelling and a partial translation of obsolete Dutch rijksdaler (= contemporary Dutch rijksdaalder), i.e., one must also show the full Dutch word (in its now obsolete spelling). Does Afrikaans enter the picture as far as use of rixdollar in South African English is concemed? Also, like abbreviation (section 9) and transliteration (section 6), anglicization is often used loosely in this dictionary, as here.

robot The etymology given is "fr. Czech robot 'work' poss. automatic." It is unclear what "possibly automatic" means. With a word like this, the compilers had two choices. First, because robot was not coined in South African English (only the meaning 'traffic light' is a South African innovation), no etymology could be given (the reader wanting to know the origin of the word would consult a general-English dictionary). $n$ The compilers followed that procedure at exile and vigilante, where no etymology appears. Second, the etymology could have begun "< general-English robot 'automaton' < Czech...." The compilers 
followed neither procedure at robot, thus implying, unjustifiedly, that South African English borrowed the word from Czech. The etymologies at litre / liter, location, Malay, safari, tricameral parliament, and ululate are likewise misleading. ${ }^{23}$ On the other hand, no etymology is given for several words which do need one: aanbod, apteek, karmenaadjie, Louis 'the train which takes National Servicemen home after completing their period in the forces' (why is it so called?), oorskiets, and ruggerbugger. Earlier comments in Gold 1989a: 252-253.

rood The etymology given is "Dutch measure." Dutch roede is not just any measure but precisely this measure, hence the etymology should read "Dutch roede 'idem'." Reference to the English cognate rod (a different measure, however) would be appropriate.

scale The etymology given is "fr. Eng. scale 'a drinking bowl', Du. schaal, Ger. Schale." For phonological reasons, neither the Dutch nor the German words would yield the English one. Only English is its source.

shebeen The glottonym used in the etymology, Gaelic, should be replaced by Irish, which is the official English name of the Celtic language of Ireland.

spider The etymology given is "fr. wheels." A bit of amplification would not hurt: "from the size and shape of its wheels."

stand 'urban plot or piece of land'. The compilers say "prob. fr. Afk. ..., poss. U.S." This usage is probably of Afrikaans origin and the American one probably of New Netherland Dutch origin, hence an instance of convergence (cf. can't complain in section 4).

stokvel "Etymology unknown." The spelling suggests that Afrikaans may be the immediate source. Could not the first syllable be (ultimately?) from English stock (as in stock market)?

tarentaal The etymology given is "poss. fr. Lat. Terra Natal." Natal is presumably a misprint for natalis, but even so, Làtin "terra natalis appears to be nonexistent (though solum natale 'native soil' exists). The spelling suggests that Afrikaans may be the immediate Afrikaans source; and from the 1827 citation one infers that the Afrikaans word, if such exists, is of African origin.

thank you 'Equiv. of "no thank you".... The etymology given ("trans. Afk. fr. Du bedanken 'to decline, refuse"') should be changed to "trans. Afk. dank $u<$ Dutch dank u." Thus, in Dutch, Afrikaans, and South African English, 'thank you' is used both in accepting and in refusing. It may be added that 'thank you' when declining something (found in Yiddish, Israeli Hebrew, American English, and possibly other languages too) is an ellipsis of 'thank you for 
inviting me', 'thank you for offering', etc. Dutch bedanken is irrelevant to the foregoing semantic development, hence should not be cited. Earlier comments in Gold 1986a: 138 and 1989a: 252.

thumb, suck out of the... The etymology given is "fr. Afk. fr. Du. iets uit zijn duim zuigen." It implies that suck...out of the thumb is used in Afrikaans. To avoid that misinterpretation, the first "fr." should be replaced by "translation" and the Afrikaans idiom should be specified. The etymology may be taken back further, since the Dutch idiom is a translation of German sich [etwas] aus den Fingern saugen. 24

ting-tinkie Part of the definition is "The name is onomat." (which is an etymology and should thus go where the compilers intended to put such information). Immediately after, however, the etymology "Afk. tingtinkie onomat." is given. If so, the English word is not onomatopoetic, but a borrowing of the Afrikaans word (and it is only the latter which is onomatopoetic).

tokkelok 'a theological student at an Afrikaans university'. The etymology given, "prob. fr. Lat. and Du. theologicus 'theologian', poss. rel. Gk. theoklētoi 'called by God'," should note that the English word is derived from Afk. tokkelok. The compilers suggested the Greek word presumably because it has a $/ k /$, which could explain the $/ \mathrm{k} /$ 's of the Afrikaans word. A more probable explanation is that a clipping of theologicus, viz. 'theolog, would yield the desired final $/ \mathrm{k} /$ (the $/ \mathrm{g} /$ of "theolog, being word-final, would be realized as $[k])$ and a fanciful or expressive doubling of $[k]$ would yield the medial one.

tot siens The etymology given, "Afk. tot 'until' + siens 'see(ing)'," implies that English-speakers combined two Afrikaans words to form a pseudo-Afrikaansism in English. Rather: < Afk. tot siens < Dutch tot ziens = Dutch tot + Dutch ziens. 25

town house The etymology given for this word as used in both South African and American English may be expanded: until a few years ago, town house was used in American English only in its traditional sense of 'urban mansion [in contrast to its owner's or occupant's country residence]'. Since only the rich can afford the luxury of two sumptuous homes, town house had, and still does, conjure up images of great wealth. Developers seized on the connotations of the word and began using it in a new sense to boost sales. It is in this new sense, first used by American developers, that the word entered South African English (as far as I can tell, British English still uses the word only in its traditional sense). The compilers quote "Barnhart $A$ Dict. of New English: 'U.S. an attached one-family house: row house'," but row house and town house have different connotations: "row house: one of a set of houses, contiguous and usually identical, built as a group by a developer for sale or rental and produced in 
Manhattan from the 1820 's to the 1890 's. Generally 15 to 20 feet wide; from 1860 to 1880 usually faced in brownstone, but thereafter also in brick, limestone and other materials" vs. "town house: a town house may have the same dimensions as a rowhouse but it differs in having more expensive finishes and a unique facade unmatched by any neighbor's, automatically suggesting that it rises above the mass-produced to the level of the custom-made. Beyond 25 feet in width, the town house begins to overlap with the mansion" (both definitions are from Gray 1992, which refers to Manhattan not because rowhouse is used only in New York City English [it is universal in American English] but because this article happens to deal with that part of New York City). South African English town house in the sense in which the compilers list it is thus an Americanism.

Tuk-Tuk 'a three-wheeled taxi'. The etymology given is "unkn. perh. onomat." The word is probably echoic of the puttering sound of the motor. Cf. Israeli Hebrew tus-tus 'motor scooter', likewise echoic of this sound. See also pompom.

Turnhalle The etymology given, "Ger. turnen to perform gymnastics + Halle hall," wrongly suggests that an English-speaker in South Africa coined Turnhalle by combining two German words. Read " $<$ Ger. Turnhalle = German turn[en] 'to perform gymnastics' + German Halle 'hall'."

turnoff The word presumably should be deleted from the etymology.

uncle This word, labeled "Indian usage," is defined as 'a mode of address to a man of any age whose name is unknown'. The etymology given is "ety. unkn., poss. fr. uncle1." In India, it is customary to show honor to a parent's friend by calling him 'uncle' or her 'aunt', but that mode of address is not used in other circumstances, viz., to strangers or anyone whose name is not known. Either, then, the Indian South African English usage which the compilers note is an innovation (when compared to usage in India) or they have described it incorrectly (the former is probably the case, inasmuch as the two citations which they give support their definition). In several languages, by the way, words meaning 'aunt' and 'uncle' are used vocatively to call the attention of an adult whose name is not known (or otherwise address that person), for example, Yiddish (mume to a woman and feter to a man).

waatlemoen The etymology given is "Afk. metathesis fr. Du. watermeloen or fr. Jan van Riebeeck's waterlimoenen, attested from the entry in his diary dated 17 December 1652." Afrikaans presumably continues van Riebeeck's usage (see note 28) and in his speech this form was presumably due to metathesis, unless, perhaps, it can be attested for pre-1652 Dutch.

The etymology of certain place names entered in this dictionary needs to be treated with greater consistency. The three possibilities are [i] from Dutch, [ii] 
from Afrikaans, or [iii] from Dutch and Afrikaans. Here is one example of each of the different treatments which were found in the edition under review: 26

-sig- "Afk. sig fr. Du. zicht." Correct, since the English form can be only from Afrikaans.

gracht "Du. gracht Afk. grag 'moat, canal, ditch'." Since the English form is only from Dutch, the Afrikaans word should be omitted or, at most, be preceded by "cf." or, even better, by a right-facing caret: "< Du. -gracht (> Afk. grag) 'moat, canal, ditch'."

-gedacht "Afk. gedag fr. Du. gedacht...." This English form, like gracht, is of Dutch origin, yet Afrikaans is given even more prominence here than in the previous entry. The arrangement suggested above is needed here too: " $<\mathrm{Du}$. gedacht (> Afk. -gedag)."

gelegen "Afk. geleë." This etymology is even more misleading than the previous one because Dutch is not mentioned at all. Dutch-gelegen is the sole source of this word.

groot- "Afk. fr. Du. groot...." Here, both Dutch and Afrikaans provide a possible etymon. Both languages should be given equal prominence, with Dutch in first place because it is chronologically prior: "< Du. groot- and Afk. groot-." The same remarks apply to groen.

jag also jacht The etymology should make it clear that the first word is from Afrikaans and the second from Dutch. The examples could be rearranged accordingly.

verwag "Afk. fr. Du. verwachten 'to expect, look forward to'." That is correct, but then three of the five examples contain Dutch -verwacht (two having Afrikaans -verwag). Separate entries, and corresponding etymologies, are thus needed for the Dutch-origin and Afrikaans-origin forms. ${ }^{27}$

Deemphasis or overemphasis of Afrikaans or of Dutch is seen in other entries too, like knecht, the etymology which the compilers give being "Du. knecht... Afk. kneg..." (read "< Du. knecht [> Afk. kneg])" and maasbanker, for which they give "fr. Du. marsbanker 'horse mackerel"' (read "< Afk. < Du. marsbanker").

On the other hand, proper emphasis is given in laagte ("SA Du. laagte / leegte..."), though it is questionable whether it is necessary to say South African Dutch instead of Dutch. Inasmuch as South African English has not borrowed from any non-South-African variety of Dutch, the simple name Dutch, in etymologies of South English lexemes and meanings, can be used without ambiguity to mean 'Dutch as used in South Africa'.28 


\section{Prescriptivism}

The considerable influence of other South African languages on South African English is evident on every page of this dictionary. With every sign that politi$\mathrm{cal}$ and social changes of recent years will continue, contacts between different peoples in South Africa can only increase, the inevitable result being ever greater influence of one language on another. Indeed, most of the usages recorded in this dictionary are of non-English origin and some of the citations show strong influence of Afrikaans on South African English (a comparable dictionary of Afrikaans would presumably reveal the considerable influence of English). That South Africans themselves are not unaware of the interpenetration of English and Afrikaans is revealed by the word Anglikaans (q.v.) and the citations which the compilers give for it. ${ }^{29}$ In the absence of significant rewards and punishments for linguistic behavior, purism is bound to fail. Observers of the linguistic scene may thus condemn or promote this or that usage, but they can expect little success outside a small group of fellow purists. Furthermore, for language engineering even to have a chance, suitable equivalents must be proposed for the condemned forms (see note 11). This dictionary often suggests them but not always.

Some of the forms which the compilers condemn sound natural to an American ear, but then what is acceptable in American English may not be in South African English (Gold 1989a: 252). At any rate, here are a number of forms which the compilers do not fully accept and which caught my attention: they label -water in compounds like sugar water and vinegar water as substandard, presumably because they think it is "probably transferred from Afrikaans usage or obsolete British English." Is either of those reasons justified? Applying such a criterion, one would have to reject countless South African English usages. The construction is perfectly natural in English (cf. rose water, salt water, etc., etc.). Indeed, the compilers accept tea-water (hyphenating it as a main entry and spelling it as an open compound s.v. -water ${ }^{30}$ ) and refer to Jamaican English sugar water (their mention of Indian English butter-bread should be deleted as irrelevant).

They do not characterize as substandard (but label as a "mistranslation of Afrikaans vol 'covered with"') full of 'covered with / in', as in "the tube is now full of red patches" and "his shirt was full of blood" (an additional citation is found s.v. nunu). One could be a little less condemnatory by saying "literal translation" instead of "mistranslation" (also, read vol met for vol in the etymology). This usage is found in Ashkenazic English too, e.g., "Your pants are full of mud" (a literal translation of Yiddish ful mit 'covered with').

It is unclear why the compilers found something noteworthy in the sentences [i] "If he had to be confronted single handedly we fear he could kill" and [ii] "If she had heard of it she would have shrieked with laughter." In traditional prescriptive grammar, the sequence of tenses in contrary-to-fact sentences is [a] "If she has time, she will do it," [b] "If she had time, she would do it," and [c] "If she had had time, she would have done it." Sentence [i] corre- 
sponds to [b], and [ii] corresponds to [c]. The compilers propose that have to and had to should be were to. That is a possible (but not obligatory) substitute in [i], but not in [ii] (where the substitution in the protasis is possible only if we change the tense in the apodosis: "If she were to hear it, she would shriek with laughter").

The compilers do not label as substandard finish and klaar / finished and klaar, but they do say it is "redundant" or "tautologous" (s.v. redundancies), which is a bit condemnatory. This expression has stylistic value (which they in fact recognize s.v. finish[ed] and klaar: "emphatic expression"). Indeed, who is to throw the first stone? The compilers' description of a "transliteration," quoted above, contains the words "e.g.,... , etc.", only one of which is needed. ${ }^{31}$

S.v. verbs, we read that "South African English contains numerous deviant verb forms." "Deviant" from what? From British English? If so, to be logical, one should apply this criterion across the board and label ANY South African English "deviation" from British English as substandard. If from Standard South African English, that should be stated. Nonstandard would be a fairer description than "deviant."

Noo-noo is called an "erroneous form of Zulu nunu." Alternative spelling would be a fairer description. Also, the word Zulu should be deleted, for nunu is English.

Can't complain is for some reason labeled "substandard."

If Prog is labeled colloquial, should not Nat and Sap be too?

\section{The form of entry heads}

The following entry heads probably include an instance of each of the kinds that can be improved in this dictionary: [a] Boer en / met sy roer, [b] (ge)moed, [c] kleilat(jie), [d] kyk, ky-daar, [e] mother, small, big. [f] road, in the, out of the, [g] springhaas, springhare, [h] uitpak inspeksie, inspection, [i] umzimbete, -beet, -biet, and [j] want to, doesn't / don't. The compilers' goal here was to save space, but a tiny extra expense would have been worth the resultant clarity. In [a], probably all sophisticated users of dictionaries will understand that either en or met is used in this lexeme. In [2], however, a serious problem arises: the entry head appears under the letter $m$, hence someone looking for gemoed will not find it (under the letter $g$, no entry for gemoed is given, not even a cross-reference to moed), hence the word is unlocatable except serendipitously. In [3], sophisticated users will understand that the parenthesized material is optional. In [d], a problem arises: does the entry head as given mean that kyk is a lexeme in its own right or, rather, that, besides $k y$-daar, one can say kyk-daar? Presumably the latter inference is the correct one (though both are possible), but why not 
make things clear? In [e] and [f], we have two backtracking entry heads fused into one. The space saved is at the price of clarity (see presently on backtracking heads). In [g], the form of the entry head is impeccable, but the etymology is not fully coordinated with it: "Afk. fr. Du. ..." suggests that springhare is an Afrikaans word, when only springhaas is, with springhare being an English translation of it. In [h], we have something similar to [d]: presumably, uitpak inspection is an alternate form (and not just inspection). In [i], sophisticated users will understand that umzim-remains invariable while what follows it can take one of three forms. And [j] is similar to [e] and [f]. Hence most but not all of the ambiguities are resolvable through logical thinking, though an explicit indication of the various forms would have been optimal.

If a lexeme consists of more than one orthographic word, how to list it is not always straightforward. The trend in contemporary lexicography is away from backtracking entry heads, for example, not blink kant bo, hou die, but hou die blink kant bo (Gold 1989a: 248-249). This dictionary contains many backtracking entry heads, e.g., [i] blink kant bo, hou die; [ii] bones, throw the; [iii] Chicken Run, the; [iv] Compagnie, Jan; [v] Company, the; [vi] thumb, suck out of...; and [vii] time, in... They have several disadvantages and, it seems, only one advantage:

A. Logically, the order of elements in multiword entry heads should be their actual order, i.e., iconic order (natural order) in the heads is best.

B. It is often difficult to decide under what noninitial component such entries should be listed, hence, for uniformity's sake, the lexicographer should alphabetize them by taking into consideration all of their letters (ignoring spaces), i.e., as if each entry head consisted of a single orthographic word.

C. In that way, the user will never be in doubt where to look for such items: in their normal alphabetical place. ${ }^{32}$

D. The only disadvantage of iconic entry heads is that the first element is often a mere function word, which no one would think of checking first, e.g., $a$ bean, the Cape, and in commerce. Yet a solution is at hand: use iconic order but disregard any initial function word for purposes of alphabetization. Thus, $a$ bean will appear in its alphabetical place under the letter $b$ (i.e., as if it were merely bean) and the Cape and in commerce in their alphabetical place under the letter $c$ (examples in sections 2 and 4). The function words are thus disregarded for purposes of alphabetization, but they occupy their normal place in the lexeme. That means that under the letter $b$, for example, an entry will begin with the letter $a$, but no matter. 
Furthermore, as often happens in dictionaries with backtracking entry heads, the compilers forget themselves and backtrack some entries but not others, though all are identical in structure. For example, the fourth edition of $A$ Dictionary of South African English has Ethiopia, Order of and Good Hope, Order of, but Order of Death. Why backtracking order in two instances and iconic order in one?

\section{Abbreviations, acronyms, and letterwords}

Like earlier editions of A Dictionary of South African English (Gold 1986a: 130), this one confuses abbreviations, acronyms, and letterwords (SAI, SATV, and $S S B$, for example, are labeled "acronyms," though only the first should get that label, the other two being letterwords). The fourth edition adds a further consistency: "abbreviation" is used to characterize clippings and shortenings too (e.g., rat pack, from ration pack; see also note 19 and syppo in section 6).

The fourth edition often shows the pronunciation of acronyms and letterwords (however haphazardly or incorrectly they may be labeled as such), but not always. Sometimes their pronunciation may be reasonably presumed, but not with certainty (SSU is probably a letterword, though it could also be an acronym, homophonous with sue and Sue). Even some lexemes which are letterwords require an indication of their pronunciation: should $S S$ be pronounced as two separate letters or, rather, as if it were spelled "double S"? That the latter is a possibility is shown by the American English letterword NAACP, which is pronounced as if it were spelled "N, Double A, C, P." And in many cases, even a reasonable guess is impossible, e.g., for SATA and SATS. Are these letterwords? Acronyms? Both (depending on the speaker)? If acronyms, how is the vowel after the /s/ pronounced?

The tendency in English is to convert letterwords into acronyms if they are pronounceable acronyms. In recent years, when founding an organization or other group, people often pick a pronounceable, catchy acronym FIRST and THEN find suitable (or not so suitable) words by which to resolve it, e.g., $M A D D$ 'Mothers Against Drunk Driving', pronounced like English mad (chosen because the mothers are "mad," i.e., angry, that people are being killed as a result of drunk driving). Yet that is only a tendency. For instance, generalEnglish UPI 'United Press International' and South African English UP 'United Party', though pronounceable as acronyms, are still letterwords. What about South African English ZAR? Is it a letterword? An acronym? The compilers label it an "acronym," but since they don't use the term letterword, we don't know what they really mean by the word "acronym." Furthermore, even if the status of a word is indicated, it may have more than one pronunciation, e.g., Unisa, which the compilers treat correctly both with respect to labeling ("acronym") and pronunciation (two are shown). Precise terminology and indication of the pronunciation where necessary would therefore be welcome. 


\section{Hidden lexemes}

The compiler of a dictionary presupposes that its users have some knowledge of the language(s) in question: in writing a dictionary for children or for nonnative learners, one presupposes less; for adult native speakers, more. The compiler also supposes that certain compounds need not be defined if their constituents are (like non-essential if non- and essential are). Once that presupposed knowledge is discounted (it is assumed, for example, that users of $A$ Dictionary of South African English need no explanation of general-English words used in general-English senses like apple 'apple' and seven 'seven'), everything else must be explained, that is, any lexeme or sense of a lexeme which is found anywhere in the dictionary and which meets the compiler's criteria of frequency, range, etc. for inclusion should be entered and treated (in this case: if the item is a South Africanism [however the term South Africanism is defined]). This edition, however, contains many items that should be treated but are not (= hidden lexemes or hidden senses), for example, cat's eye (s.v. tiger's eye), dop system (s.v. tot system), ek moet waai (s.v. waai), Gay-gevaar (s.v. khaki33), hermitage 'cinsaut' (s.v. pinotage), housemanship (s.v. Zimbabwean; the American English :equivalent is either internship or residency [I am not sure which]), ijuwishi (s.v. Jewish), iron (s.v. breker), Joburg (s.v. breker), melkboom (s.v. naboom), panser ou (s.v. boknaaier), red cat (s.v. ride on water), Russians (a food; s.v. slap), rustbucket (s.v. Vaalie), skoon (the sense in which this word is used in the last citation for fransman is not entered, though it is given for schoon), stock-proof (s.v. jackal-proof fencing), stokies (s.v. sloffies), unban (ss.vv. $A N C$ and $S A C P$, and p. ; ban is entered ${ }^{34}$ ), varkhok (s.v. mooi-moois), vermin-proof (s.v. jackal-proof fencing), Volksie 'Volkswagen' (s.v. tom; the American English equivalent of this informalism is Volks), and Woltone (s.v. Blikoor). Earlier comments in Gold 1986a: 130-131 and 1989a: 246-247.

\section{Blind references}

Blind references are verboten in all kinds of scientific writing, but this edition contains many. At community of property, for example, the reader is invited to "see...kinderbewys," but no such entry is given. More blind references are found at dinges ("see also goodie"), Durbs ("see under ek sê, Natal Fever and soppies," but the first and third are blind references; a cross-reference to spiel would have been appropriate, especially since the entry for this word contains a citation for Durbs which is older than that given at Natal Fever), moffie ("see trassie"), plaats ("see bewaarplaats"), tickey drive ("cf. beetle-drive"), tree aan ("see also aantree"), and Wees- ("cf. Boedelkamer"). See also note 39. The fourth edition being smaller than the third, one may infer that the publisher limited the number of pages for the new edition drastically. If so, the blind references came about when the 
compilers deleted entries in the third edition for the fourth one without also deleting references to them elsewhere in the dictionary. 35

\section{Layout and typography}

The forbidding layout and typography of premodern dictionaries - little blank space, hardly any indentation, little use of various typefaces to make the different parts of the entry clearer and the location of material easier - have been abandoned in favor of a more sensible, attractive, user-friendly arrangement. Compare, for example, the Grimms' Deutsches Wörterbuch, the Groyser Verterbukh Fun Der Yidisher Shprakh, or the Oxford English Dictionary (including the second edition) - all three are old-fashioned in their layout and typography - with A Dictionary of Americanisms on Historical Principles, A Dictionary of Canadianisms on Historical Principles, the Dictionary of Bahamian English, the New Dictionary of American Slang, and the Dictionary of American Regional English, which are a pleasure to use.

A Dictionary of South African English tends toward the older arrangement. Although the entry head is easy to spot (it is in boldface and the entry has a hanging indentation), a line is not skipped between entries (possibly because of limitations of space imposed by the publisher) and, more importantly, an efficient use of typefaces is not made within the entries (which is certainly not due to constraints of space).

Too much italic font is used in the etymologies, e.g., "[presum. fr. half bottle]" (s.v. half-jack) or "[Afk. gril shudder]" (s.v. gril). Italics as the unmarked font is annoying, since the convention in English is to use roman in that function, with italics only for special functions. For example, "Iprob. fr. Tamil, Urdu, Telegu, etc. kuli labourer, also Chinese]" (= the etymology s.v. coolie) could be given as "[prob. fr. Tamil, Urdu, Telegu, etc. kuli 'labourer', also Chinese]" with no loss of information but with considerable less distraction to the eye.36 Or, "Itrans. Afk. vb. phr. 'wag op' formal 'wait upon' usu. in biblical contexts]" (= the etymology s.v. wait on) could be made easier on the eyes if it read "[trans. Afk. vb. phr. wag op 'wait upon', a formal construction usual in Bible translations]."

Excessive use of italics could at times lead to misinterpretation: if English has a lexeme Hong Kong flu, one might take the compilers' "Hong Kong hui, mutual savings club" (s.v. stokvel) to refer to a supposed English lexeme Hong Kong hui, whose meaning is 'mutual savings club'. What they meant was "Hong Kong English hui 'mutual savings club'."37

The compilers' use of single quotation marks is so haphazard that at times you can't tell whether something is a lexeme or a definition. For instance, part of the entry for happy box reads:

A cardboard 5-liter or 2-liter wine container with spigot. Also occ. 'suitcase wine'. 
Is 'suitcase wine' an occasional synonym of happy box (if so, it should be italicized, without quotation marks) or is it an occasional meaning of happy box? If suitcase wine is a synonym (i.e., a lexeme), it is a hidden lexeme, for it does not appear in its alphabetical place under the letter $s$. If 'suitcase wine' is a meaning, suitcase or suitcase wine needs to be entered since this use of suitcase is not general English.

The compilers use single quotation marks around certain entry and subentry heads too: 'Gaygevaar', 'happen', 'Kaffir taxi' (labeled "slang"), 'number gangs', 'terrorist' (labeled "colloquial"), 'Town Talk' (labeled "colloquial"), Young Lions usu. 'Young Lions' (see also note 30). The lexicographical convention is to show that a usage is informal, humorous, nonstandard, substandard, etc. by a label, as the compilers indeed do for three of these items. To use single quotation marks is misleading because that implies they are part of the citation form and, consequently, the lexeme is always so spelled or should be so spelled. Yet the former is certainly not the case (the citation at 'Town Talk' has no quotation marks) and the latter should not be the case. Also, to label an item ("informal," etc.) and to use quotation marks around it is superfluous. Just the label is enough.

Information is frequently misplaced in this dictionary (cf. com-tsotsi, concentration camp, smous, and tumed in section 3 and ting-tinkie in section 6). Field and usage labels normally come before definitions in this dictionary, but not always. How, for example, should the label at stook be interpreted: "To distil spirits: see stoker. Slang. To stir up trouble: see opstoker"? Does the word slang apply to what precedes, to what follows, or to both? Also, special typography is used for stoker but not for opstoker, although both have the same status: a cited form. Presumably the absence of italics for opstoker is a misprint.

At student, the usage label is part of the definition: 'A black school child, now in regular use'. It's the word, not the child, that's in regular use, hence "Now in regular use" should have gone into the paragraph reserved for "information or comment not strictly part of a definition" ( $p . x x i x$ ) or, even better, these words can be omitted entirely, since only non-current items need be labeled ("obsolete," "archaic," "historical," etc.).

The convention in lexicography is to number the definitions if more than one is given, but what will be found in this dictionary is anyone's guess: the compilers follow the convention in most cases, but not ss.vv. koeksister, rooivalk, spitskop, stook, and other words. The first entry for queen has a numbered definition, though it is the only one (a second definition - unnumbered - does, however, appear in this entry, but it is given in the paragraph reserved for "information or comment not strictly part of a definition" [p. xoxix]).

Etymologies may appear anywhere in the entry (cf. bakkie in section 6). They are usually given in brackets at the end of the entry (where the compilers intended them to be), but also:

after a label and before a citation (as at mpata, where the etymology, "Zulu -mpatha 'novice, greenhorn, ignorant person'," is - unconvention- 
ally - intended to serve as the definition [no explicit one is given] of English mpata),

[2] as a spatial label (as at kangaroo court, where, if one reads the entry strictly, one concludes that the South African English lexeme kangaroo court is used not in South Africa but in Australia), and

[3] in the paragraph reserved for "information or comment not strictly part of a definition" (as at Kuhne meal, where we read: "Thought to be the name of a German doctor who developed the 'health loaf' at the turn of the century, 'to clear up the illnesses prevalent at the time,"' this referring only to Kuhne and not to Kuhne meal).

The entry for poenskop / poeskop has two definitions, each numbered and each with an etymology. The first etymology is "Afk. poena 'a polled animal' + kop 'head'" (which incorrectly suggests that the compound was formed in English [cf. bywoner in section 6]) and the second is "fr. Afk. poena 'polled animal', presum. fr. appearance" (which cannot be fully correct for it does not account for $-k o p$ ). It is likelier that the second sense is a metaphorical use (which arose either in South African English or in Afrikaans) of the first one, hence an etymology should appear only for the English word itself and not for any of its meanings.

At heemraad, the etymology appears at the end of the first definition, though it should apply to the word in both its senses.

At induna, five senses are given (only the last four being numbered) and the etymology is given after the unnumbered sense.

Sometimes the order in the etymology is illogical, e.g., at tweegatjakkals: "[Afk. 'two hole(s)' tweegat jackal]". A clearer wording would be: "[Afk., lit. 'two-holed jackal']."

The compilers seem to have set themselves no guidelines on which to list noun plurals and how to list them. Some dictionaries show a plural for every count noun and some show a plural only if it is irregular. In this dictionary, however, we meet with a number of contradictions: from the absence of a plural at vabond one may assume that it is regular (vabonds). If so, no plural is needed at the immediately preceding entry either (vaatjie / vatjie), for it too is regular. Yet one is shown (-s). The entry before that one is Vaalpens, whose plural is irregular (Vaalpense ${ }^{38}$ ), yet no plural is shown.

Synonymous forms appear in no fixed place: after the part-of-speech label and before the definition (e.g., at jag, tiger's eye and tjap) or as part of the definition, preceded either by a comma (e.g., at snaphaan) or by a colon (e.g., at sloffies).

Superfluous information is not infrequent in this dictionary (see ewe, off, and smous in section 3 and bilingual and by in section 4). Definition-openers like "In freq. use in SAE sig." (s.v. farm), "Term for" (s.v. mbombela) and "Name 
like "In freq. use in SAE sig." (s.v. farm), "Term for" (s.v. mbombela) and "Name for" (s.v. Louis) are needless, waste space, and give the dictionary a Victorian air.

Alternate pronunciations are separated by commas in this dictionary, but at swart-, where three pronunciations are given, the third one is parenthesized, without a comma separating it from the second one. How should that typography be interpreted?

The two words after grondaar appear in roman and the first one is capitalized. Nothing else at this word is interpretable as its definition, hence one assumes that these two words ("Drug users") are its definition. In point of fact, they constitute a field label and the reader is supposed to guess the definition from the citation (which is no easy task). S.v. arm 1 , the same field label is italicized and thus easy to distinguish from the definition; perhaps then at grondaar the error is merely a misprint.

Part of the entry at tickey box reads "also - "phone," which implies that an additional form is "tickey box phone." To generate the correct form (tickey phone), "also - 'phone" should be placed s.v. tickey.

\section{Graphic illustration}

The value of this dictionary would be enhanced with the addition of graphic illustrations for South African flora, fauna and other realia which it mentions (Gold 1986a: 144). The fourth edition takes a step in this direction with pictures of African beadwork, an assegai, Barberton daisy, calabash, Cape cottage, coral tree flower, jacopever, kraal, ramkietjie, and sunbird on the cover. Many more pictures or drawings would be useful (e.g., for bekslaner hek; see section 3). Earlier comment in Gold 1986a: 144.

\section{Material of Jewish interest}

As a student of Jewish aspects of English, I am interested in Jewish aspects of South African English and Afrikaans. ${ }^{39}$ Some questions to be answered in an investigation of this nature are: To what extent do Jews in South Africa use each of these two languages? How do they use them, that is, to what extent does their English or Afrikaans reveal that they are Jews or, phrased differently, to what extent may one speak of Jewish South African English and Jewish Afrikaans? What Jewish aspects of non-Jewish English and non-Jewish Afrikaans need study, for example, to what extent has the English or Afrikaans of Jews influenced that of non-Jews? What lexemes in English and Afrikaans are of Jewish interest (like words meaning 'Jew', 'rabbi', and 'synagog' or sayings and proverbs referring to Jews)? What usages have been attributed to Jewish influence but are actually of a different origin altogether?40 What com- 
guages?41

Although the best student of a language is often a linguistically trained participant-observer, nonparticipant observers trained in linguistics, if they recognize their limitations, can make a contribution too. Having never been to South Africa and not being a speaker of South African English, I fall into the category of an observer so trained (Gold 1986a discusses and demonstrates the appropriateness, for contrastive linguistics, of linguistically trained allotopolectal and allolingual observers). 42 Thus, for about twenty years, I have been reading South African English publications, both Jewish and non-Jewish, and have been listening to and querying, orally and by letter, both Jewish and non-Jewish speakers of South African English and Afrikaans. I therefore sit, as it were, on the shore, scrutinizing the swimmers, but not jumping in myself. Mere observation from the sidelines can in fact be a benefit, for it gives one the vantage which Archimedes, in a different respect, longed for ("Dos moi pou sto kai kino ten gen").43

The foregoing applies to synchronic study of Jewish aspects of South African English and Afrikaans. For diachronic studies (e.g., in etymological research), a different set of skills and body of knowledge are needed (indeed, if one had to be a native speaker or even any kind of speaker of a language in order to carry out diachronic investigations, we would now have no students of Classical Latin, Classical Greek, Biblical Hebrew, Proto-Indo-European, and countless other languages). In this regard, the principal requirements are knowledge of the prelanguages of South African Jewry (for earlier South African Jewry, chiefly Western Yiddish; for contemporary South African Jewry, chiefly Northeastern Yiddish) and acquaintance with other situations in which Jews and non-Jews have been in contact (in the present instance, contact in the Dutch-speaking and English-speaking areas of Europe, inasmuch as some items of Jewish interest in South African English probably traveled this route: Yiddish $>$ Dutch $>$ Afrikaans $>$ South African English or Yiddish $>$ Dutch $>$ British English $>$ South African English). From the diachronic perspective, we see that first-hand (i.e., native or primary) knowledge of South African English or Afrikaans or even residence in South Africa or a visit is not necessary because etymologists reconstruct events which happened long ago, with information and tools that may be acquired anywhere in the world (one may study the origin of the Latin word telum, for example, just as easily in Tokyo as in Rome).44 The origin of Jewish South African English kitke, for instance, is to be sought far away from South Africa, in an environment having nothing to do with it. For this word, only one's knowledge of Northeastern Yiddish, of Slavic languages, and of the different shapes which the Sabbath and holiday loaves baked by Ashkenazic Jews may take comes into play (Gold 1984c). 45 The foregoing is not to say that one MUST be a non-South-African to study Jewish aspects of South African English or Afrikaans diachronically, only that one need not be.

The impetus for Jewish studies in South Africa has come, first and fore- 
most, from Afrikaans-speaking churches. That is, because certain Afrikaners have likened themselves to the Israelites, they have taken a special interest in Bible studies, which has led to an interest in the early history of the Jewish people and in Biblical Hebrew. That, more or less, is the extent of Jewish studies among non-Jewish Afrikaans-speakers. Among non-Jewish English-speakers in South Africa, interest in Jewish studies has also been limited mostly to Bible studies. Those fields of research, however, are irrelevant to the study of Jewish aspects of South African English or of Afrikaans (like the etymology of chattes, gabba, kitke and smous).

With respect to Jews in South Africa, whatever may fall under the rubric of Jewish studies has been mostly of an elementary nature: the preparation of boys for their bar-mitsve (at age 13) and the operation of some Jewish supplementary schools at the primary level. None of that qualifies anyone for linguistic research any more than preparation for one's first communion in the Roman Catholic Church makes one a Latinist. Jewish studies extending beyond Bible studies began at some South African tertiary schools a few years ago, but they are embryonic and will probably remain so, inasmuch as the Jewish community, which is the single chief source of students interested to any significant degree in Jewish studies aside from Bible studies, continues to assimilate to the coterritorial English-speaking White community and thus shows little interest in serious Jewish research of any kind. The immense stores of Jewish knowledge which immigrant generations of Jews brought to South Africa have by now vanished almost completely, so that today's average SouthAfrican-born Jew, especially if two or more generations removed from the immigrant generation, is so anglicized, South-Africanized, de-Judaized, and kuglized or beyglized that what little goes under the rubric of Jewish studies in South African tertiary schools, aside from Bible studies, will likely remain introductory or elementary and, in any case, these elementary courses do not even mention (let alone treat, not to speak of preparing one to investigate) Jewish aspects of South African English or of Afrikaans. South Africa can boast of no Yiddish scholarship (one of the prerequisites for the study of Jewish aspects of South African English and of Afrikaans), hence it is not surprizing that, although Jewish South African English is a reality, no one in South Africa, Jew or non-Jew, has ever investigated it scientifically (a brief word list by a participant who was not a trained observer did appear in the 1930s, but it is full of mistakes). As for Afrikaans, how Jews have used this language is an untouched subject.

Therefore, it is one thing for the compilers to record raw data from native speakers or from written sources and it is another to analyze the data synchronically. And it is still another thing to study the material diachronically. Finding Jews in South Africa (and abroad) who can provide data on contemporary Jewish usages and comment on them synchronically ("I use $x$ word in this sense: ...." or "That word connotes to me...." or "I have heard people say....") is as easy as pie, but it is another matter to evaluate the native 
speaker's usually impressionistic analysis and still another to etymologize, to delve in to the history of these usages, and to make extra-South-African comparisons with other varieties of Jewish English and with other Jewish languages. Consultants for Jewish South African English can thus REPORT their experiences, perceptions, and feelings (hopefully their reporting is accurate), but they remain CONSULTANTS, i.e., participants (because they speak the language) and observers (because they comment or are asked to comment on what they use or have heard or seen others use), but they are linguistically naive observers. That does not exclude the possibility that their observations may be right, but neither does it guarantee that their opinions are authoritative. 46

Anyone doubting that South African English and Afrikaans may be studied from even a great distance or that the only reliable work on Jewish aspects of South African English and Afrikaans has been done abroad should examine the published record.47 Let one more datum be added to that record: the fourth edition of $A$ Dictionary of South African English lists kitke, labels it "SA Jewish Eng." (how that label differs from "lewish" is not stated 48 ), defines it as "Jewish Sabbath loaf of plaited bread commercially obtainable, correctly known as challah in Hebrew' (which incorrectly implies that kitke is "incorrectly" used in Hebrew, when in point of fact no such Hebrew word as kitke exists because no one uses the word in Hebrew - a kitke, furthermore, being only a certain kind of khale [sic recte], the two words standing in a relation of hyponym to hypernym and not of synonyms to each other), and etymologizes it as follows:

Iuncert. acc. Dr David Gold (Haifa) fr. an E. European term meaning 'twist'; acc. Dr M. Arkin fr. Hebr. kikkar a loaf]

Two equally informed "doctors" legitimately differing on an etymology? Nothing of the kind. Nonlinguists follow the only "rule" they know when guessing at an etymology: "If it sounds like $x$, it must be derived from $x$." Yes, Hebrew kikar (another romanization of kikkar) could conceivably become semantically specialized ('loaf [of bread]' > 'twisted Sabbath and Jewish-holiday loaf), but the phonology is not in order: Yiddish would stress this Hebrew word on the penult, in which case the second vowel, unstressed, would be reduced to a sheva, the result being Yid. "kiker. No such Yiddish word exists. Not to worry, for the nonlinguist can still get from nonexistent "kiker to existent kitke by the only "rule" of diachronic phonology which the laity knows: "corruption" or "deformation" or "deviation" (Gold 1986a: 129-130 and 1989a: 244-246). If etymology were as simple as that, everyone would be an etymologist. Gold 1984c gives the correct derivation of Jewish South African English kitke.

Like H.L. Mencken, the Branfords are willing to believe whatever anyone may care to tell them about items of Jewish interest. One of their citations for suiwer is from a letter they received: "My wife tells me that her 'chavers' who 
are not Jewish talk about going to visit their chavers [gabbas (q.v.)] without knowing that they are using a suiwer Hebrew word." Dated 5 September 1982, the letter is signed by "M. Imber, S.C.," of Durban. We should no sooner trust a South African Senior Consultus on matters of Jewish etymology than we should trust a Jewish etymologist on South African legal matters. ${ }^{49}$

In sum, the entries of Jewish interest in the four editions of this dictionary could be improved.

\section{Misprints}

Given the fact that this dictionary cites material from many languages, it is remarkably free of misprints. Read "Harteveld" for "Hardeveld" (p. viii), "one of the black" for "one the black" (s.v. African), "from Afk. boete" for "for Afk. boete" (s.v. boetebos / boetebossie), "terrorized" for "terrotized" (s.v. com-tsotsi), "weirdie" for "wierdie" (s.v. -ie), "opzadelen" for "opadelen" (s.v. saddle up), and "limoger" for "Limoger" (s.v. Stellenbosch). Are there misprints s.v. afval ("and occ. tripe" seems to be misplaced), s.v. bok-bok ("In Roman times, mediaeval schoolchildren's Latin [...]" doesn't make sense), s.v. rand (where the compilers seem to be saying that, in sense 4, plural rand may be pronounced differently from sg. rand), and s.v. third person form of address (where "deference" would read much better than "difference")?

\section{Conclusions}

The fourth edition of A Dictionary of South African English, like its three predecessors, contains a wealth of useful material gathered during thousands of hours of reading, listening, and querying. It is, however, Partridgean in its arbitrary use of fonts, punctuation, and capitalization, in its placement of material, and in its not infrequent self-contradictions. ${ }^{50}$ Strict adherence to a style sheet and careful application of methods in contemporary linguistics, especially lexicography and etymology, are suggested. ${ }^{51}$

\section{Notes}

1 For example, only a synchronic dictionary with sufficient space or a diachronic dictionary should indicate that in contemporary South African English car is the most usual word, motorcar is used occasionally, automobile is rare, and auto is never used (I thank Solly Rechtman for this information).

2 Section in this review refers to one of its numbered sections.

3 In contrast, the Jewish English items which the compilers list and the others suggested in this review for possible inclusion are all specific to South African English or, at least, not found in 
most varieties of Jewish English.

I thank Solly Rechtman for this information.

5 "Correct" grosso modo, that is. Jean Branford's surprizing use of the word "corruption" has been noted in Gold 1986a: 129-130 and 1989a: 244-247. In the fourth edition the compilers also use "deviant" (ss.vv. so and verbs).

A few years ago, the French Department of the Loire-Inferieure 'Lower Loire' (lit. 'inferior Loire') became the Department of the Loire-Atlantique 'Atlantic Loire' because it was felt that the old name reflected badly on its inhabitants. The old name referred merely to the LOWER portion of the river, i.e., to the part closer to its mouth than the UPPER portion, but that is not how some people interpreted the "inferior Loire."

7 It would be good to discuss this label a bit because its gloss, 'historical' (p. xviii), may puzzle some readers. See also note 45 on smous.

8 At by-and-by, the label between the entry head and the definition is "Afk. E. obs." The label "(Afk.)" in this position means 'not fully assimilated, Afk. loanword' (p. xxvii), but here it is not parenthesized. Is that merely a misprint or are "Afk." and "(Afk.)" in this position to be distinguished? "E." presumably modifies "obs." (i.e., 'obsolete in English). That is, the whole label is to be read 'unassimilated Afrikaans word which is now obsolete in South African English'. Perhaps just 'obsolete' or 'historical' would have been enough, no objective distinction between "assimilated" and "unassimilated" loans being possible. The difficulty of understanding what modifies what in the etymologies is also seen s.v. bakgat: "Afk. unkn.," which means '< Afrikaans < ?', but could be misinterpreted to mean 'unknown in Afrikaans' (i.e., 'the item was coined in English as if it were Afrikaans, but it is not found in Afrikaans'). That the latter is a reasonable (however erroneous) interpretation is shown by the existence of Urban Black South African English wietie, which looks and sounds Afrikaans but does not exist in that language. See note 25.

"Church of the Intercession (Anglican / Episcopal), Broadway \& 155th Street / The Rev. Canon Frederick B. Williams, Rector / Mr. William Earle Randolph, Jr., Organist / Sunday, May 3, 1992 / 8:00 a.m. - Low Mass / 11:00 a.m. — Solemn Bilingual Mass in the Presence of the Most Rev. and Rt. Hon. George Leonard Carey, Archbishop of Canterbury" (paid advertizement in The New York Times of 2 May 1992, p. 11). Nothing in this advertizement indicates what the two languages in question are (surely not American English and British English...) and it is only from the location of the church (in a neighborhood with many Spanish-speakers) that we may guess them to be English and Spanish. Likewise, New York City newspapers sometimes carry help-wanted ads for "bilingual secretaries," it being understood that the two languages are English and Spanish.

The word may is important here: Major's dictionary "is supposed to be a supplemental dictionary of American Black English lexical and semantic usages, that is, it is not intended to be a full dictionary of American Black English but only a dictionary of those usages exclusive to American Black speakers of English or of those usages more frequent among them than among American non-Blacks. The idea is a good one..., but the compiler's subjectivism has led him to include many items which neither originated among Blacks nor are exclusive to them or even more frequent among them than among non-Blacks" (Gold 1987c: 357). Thus, the only value of this dictionary in the present context is that it attests family jewels in pre- 
1970 Black American English. When, where, and among whom this sense of family jewels originated, however, are matters for research.

Prescriptivists should give what they believe is an acceptable altemate when labeling something nonstandard or substandard. None is given here (or in some of the other entries where nonstandardisms and substandardisms are listed). See section 7.

For example, the etymology given for niks is "Afr. fr. Du. niets 'nothing'," though the compilers note (in the definition) "cf. Brit. and U.S. nix 'no, "nothing doing," nothing'." Is niks really of Afrikaans origin? Would Afrikaans / $\mathrm{c} /$ give English / $\mathrm{ks} /$ ? If not, the word is probably from British English nix (American English niks being etymologically irrelevant).

The compilers note that "Prof. N. Mansvelt in 1884 in his Proeve van een Kaapsch-Hollandsch Idioticon under poes warns that the new arrival from Holland 'takes a risk if he addresses a Cape cat' (trans.) as poes." The reason for his warning may be added: Dutch poes 'pussycat' misleads Dutch-speakers into thinking that Afrikaans poes has the same meaning. However, might not the Dutch word in fact have an additional meaning viz. 'female genitals'? (Perhaps Mansvelt was too prim to know such usages). In several languages of Europe, words literally referring to cats have figurative meanings referring to women in one way or another. Chapman 1986 gives these relevant meanings for cat in current American English slang. 'a prostitute' (since the 1500s in British English); 'to spend time with women for amatory purposes; chase and stalk women' [though here the meaning probably developed from tomcat 'to pursue male sexual activity avidly' rather than from some use of cat in reference to a woman; D.L.G.]; and 'a woman who, often subtly, attacks and denigrates other women; spiteful and malicious woman'. Specifically for Black American English, he gives cat / catty-cat 'vulva'. Spanish gata and German Katze 'cat' also have slang senses referring to a woman. One of the Eastern Yiddish words for 'female sexual organ' is the vulgarism kote, which is derived from Polish kot 'cat' (Gold to appear). The romanization reflects the pronunciation of Stanke Dimitrov.

15 See also Gold 1986a: 129-130.

16 I thank Heather Kemoff for this information.

17 Glottonymic labels are by convention placed before the items they modify, hence not "raccoon U.S."

18 Could this morpheme be derived from the $/ s /$ or $/ z /$ which most of the base forms have? In South African English Obs 'the Observatory [in Cape Town]', the source of the /z/ is clear. It would probably be wrong to conclude Obs was the first formation of this kind and that its / $\mathrm{z}$ / was later used to coin the other words cited here.

19 Likewise, off 'time off, day off is not "presumably an abbreviation of time-off," but a shortening (that the compilers are not alone in misusing abbreoiation may be seen from the first citation for off); see section 9. The word "presumably" should be deleted.

20 J.B. Berns, head of the Dialectology Section of the P.-J. Meertens Institute of the Royal Dutch Academy of Sciences, has given an etymology of Dutch klaverjas in Reply 2496/1 in Jewish Language Reoiew 5:347-348. It is not identical to the one which the compilers give.

21 The spelling of a lexeme is not, however, al ways an absolutely reliable clue to its immediate origin. Two examples: South African English boggeral / boggerall is given in this edition as being "fr. Afk. ad. bogger + all." If that is correct, we would expect this etymology: British English slang bugger all > South African English slang bugger all > Afrikaans slang boggeral > 
South African English slang boggeral / boggerall (direct British influence on Afrikaans, i.e., without South African English as its intermediary, is unlikely). It may be, however, that South African English boggeral / boggerall is merely South African English bugger all (of British English origin) clothed in Afrikaans orthographic garb, without Afrikaans being a source of the South African English form itself. See also can't complain in section 4.

This edition lists South African English tochis, tochas, and toggas (all of which are spelling variants of what is rendered tokhes in the Standardized Yiddish Romanization). The digraphs $c h$ and $g g$ represent $/ x /$ (which the Standardized Yiddish Romanization represents by $k h$ ). Since German represents / $x$ / by ch and Dutch and Afrikaans represent this sound by 8 , one might conclude that tochis and tochas are from German and toggos from Afrikaans. Yet South African English tokhes (sic recte), however spelled, is actually of immediate Nor theastem Yiddish origin (the compilers correctly note that the word, in all three variants, is from Yiddish, but they do not specify the variety of Yiddish or the etymon). Since most varieties of English (Scots English excepted) have no conventional way of representing / $/$, the devisers of these three spelling variants had recourse to non-English conventions when deciding how to romanize the Yiddish word: one picked German ch and the other Afrikaans g (Dutch was probably not relevant). The person choosing Afrikaans $g$ doubled the letter to distinguish the word from general-English togas (the plural of toga). Thus, German and Afrikaans spelling conventions are relevant here, but not German and Afrikaans themselves.

It would be good to adopt the Standardized Yiddish Romanization for the spelling of Yiddish-origin words in South African English: beygl, kugl, tokhes, etc.

A cross-reference at robot to the second quotation at verdomde would be useful because the latter entry contains information about the pronunciation of robot.

23 Safari is labeled "not SAE but widely used in SA," which sounds like a non-sequitur but actually means that the word did not enter English in South Africa.

It would be interesting to chart the spatial distribution of 'making a high-pitched trilling sound with the tongue against the palate and the teeth-ridges; ululation the sound itself made by black women on joyful or exciting occasions, often while dancing' (s.v. ululate). The custom is universal among Arabic-, Berber-, and Persian-speaking women.

24 The German idiom was the model for Yiddish oyszoygn lepesl fun finger. The Israeli Hebrew idiom matsats [davar] min haetsha is modeled on both the Yiddish and German ones.

Urban Black South African English may have a pseudo-Afrikaansism, wietie 'to talk, tell, speak to'. The compilers etymologize it thus: "unkn. poss. fr. Afk. weet jy? or weet $u$ ? 'Do you know?"." Furthermore, since it is used not only in Urban Black South African English but also "freq. in Afk contexts," it is a double pseudo-Afrikaansism, i.e., used additionally in Afrikaans as imitated by urban Black anglophones. See note 8 .

26 Bound forms, like these prefixes and suffixes, should be entered with a hyphen in the appropriate place. The entry heads are cited here as they appear in the dictionary.

The compilers divide their five examples into positive and negative ones, e.g., Goedoerwag and Onverwacht, respectively. Nooitoerwacht, however, is misplaced.

Perhaps here is the least inappropriate place in this review to suggest that the glottonym Afrikans be used retroactively to include all of those varieties of spoken Dutch used in southem Africa since 1652 which, when passed down from generation to generation, led to present-day Afrikaans, i.e., that it be used even for the period before this glottonym was 
coined. That would put an end to the old controversy of when Afrikaans began to emerge. In my opinion, Afrikaans began to emerge as soon as Dutch-speakers landed in southern Africa, when they immediately found themselves in a new environment, with flora, fauna, and other realia which they had to name. Dutch-speakers thus had to be linguistically innovative from the very beginning (not to speak of influences on European Dutch which were absent in southem Africa and influences on Dutch in southern Africa which were absent in Europe). The important words here are "began to emerge." Afrikaans as we know it today certainly did not spring into existence at once or even in a few years, but 1 do think that the Dutch brought to southem Africa did begin to differ from European Dutch as soon as its speakers landed (look at any immigrants today coming to a new country and you will see that their speech begins to change as soon as they arrive).

In his diary for 17 December 1652, Jan van Riebeeck used the form waterlimoen 'watermelon' (as the compilers note s.v. waatlemoen). That form is presumably the etymon of Afrikaans waatlemoen (contrast Dutch, which appears to have only watermeloen). Since van Riebeeck had landed in southem Africa on 7 April 1652, this is direct evidence that Afrikaans began emerging no later than just over eight months after the first Dutch-speakers landed. My guess is that it began to emerge on the very first day van Riebeeck and his group came ashore.

As long as the differences were small between European Dutch and what may in retrospect be called Earliest Afrikaans or Early Afrikaans, i.e., as long as people in southem Africa still felt that they were speaking "Dutch" (the early Dutch-speakers would have found the idea that they were speaking a different language incredible), the name South African Dutch was appropriate, but now, WITH HINDSIGHT, we see that South African Dutch was Afrikaansin-the-making, hence TODAY the name South African Dutch should not be used. Comparisons may be made between Afrikaans, on one hand, and Jewish English and Yiddish, on the other. In all countries, differences are easily found between the English of Jews and that of non-Jews (cf., e.g., the compilers' label Jewish 'in use mostly among the Jewish group'), yet they are not sufficient to warrant consideration of Jewish English as a language separate from English or use of a name for it that does not contain the word English. If, however, Jewish English were to become so different from non-Jewish English that the two could no longer reasonably be considered varieties of the same language, a unitary name would be needed for this new Jewish language (say Jewish) and it would be applied IN RETROSPECT to Jewish English, inasmuch as this new language would be an outgrowth of Jewish English. That has indeed happened to Yiddish: the name Yiddish is used retroactively to cover all antecedent varieties of what is unmistakably Yiddish, i.e., to what would earlier have been called (in whatever language) 'Jewish German'.

The term pre-Afrikaans is sometimes used for those items which are believed to have originated in "South African Dutch" and which have reflexes in what is clearly Afrikaans. However, that term does not seem apposite, for "pre-Afrikaans" is not yet Afrikaans, hence it raises the old pseudo-question of "when did Dutch become Afrikaans in South Africa," i.e., when did "pre-Afrikaans" become "Afrikaans"? It can no more be answered than "When did Latin become the Romance languages?" or "When did the Middle Ages end and the Renaissance start?" Since we are dealing with a continuum, any division into clearcut entities would be arbitrary. 
It follows that a broad gray area of varieties of speech and writing should be considered BOTH Dutch and Afrikaans, hence they may legitimately be "claimed" by both languages, although many people find that hard to accept (which is not surprizing after more than 2300 years of Aristotelian logic, whose emphasis on binary thinking often tries to force us into choosing "either $x$ or $y$ " and maintains that tertium non datur).

One must also distinguish a speech system and an individual item. People at one time were certainly speaking "Dutch" in southern Africa, but it contained (I would say, from the very beginning) items which later came to be clearly identified as Afrikaans and which, in retrospect, may now be called Afrikaans. Likewise, the speech system as a whole may in retrospect also be called Afrikaans (that is a bolder step than applying the word Afrikaans to individual items in "South African Dutch").

29 It would be interesting to compare South Africa and Belgium (Dutch and French) or South Africa and the Netherlands (Dutch and Frisian) in regard to languages in contact. Belgium is more like South Africa than the Netherlands is, for Frisian is a declining language whereas in Belgium both major languages are alive and well, as are English and Afrikaans in South Africa.

30 Likewise, the entry for Yellow-Mellow cross-refers to Mello-Yello, but the entry for the latter is 'mellow yellow'. Also, if the latter is labeled "township slang," need the slanginess of the word be emphasized (i.e., by single quotation marks)? See section 12 .

31 That is not the only place where one might ask quis custodiet ipsos custodes: the entry for omissions begins "Certain items are frequently omitted in S. Afr. speech and occ. in writing; not all these omissions are exclusively S. Afr. usage...." At least to an American ear, "all these omissions" sounds extremely informal. In formal writing we would expect "all of these omissions." Could the possibly high frequency of all the in South African English be due to Afrikaans influence? If so, all the is a frequency Afrikaansism (cf. Gold 1983). Besides frequency Afrikaansism (for South African English) and frequency Angliosm (for Afrikaans), a concept useful in the study of both languages is camouflaged form (see Reply 1513/3 in Jewish Linguistic Studies 2: 449-450).

32 Admittedly, some choices are less likely than others. The reasonable ones here are hou, blink, and kant.

33 This hidden lexeme illustrates the compilers' slight tendency toward stream-of-consciousness writing. s.v. khaaki, the undefined run-on khakigeoaar is added (correctly so); the presence of -gevarr here then leads them to add 'Grygevaar' (defined - in parentheses - as 'AIDS'). Another example is seen at stad, which is defined (correctly) as a suffix found in English place names (i.e., South African English has adopted certain Dutch or Afrikaans place names so ending without translating them): the compilers ate "Venterstad, Wolmaransstad" (correctly so because these place names are used in English), adding "and as trans. 'town' in Kaapstad (Cape Town)." Yet Kaapstad is not used in English, hence is not an example of the English use of -stad. A third example is found in the etymology for bloubaadjie (see section 6), where Afrikaans rok, though irrelevant to the derivation of bloubaadjie, is mentioned.

34 Unban is self-explanatory because ban in its special South African sense is treated, hence it need not be entered for semantic reasons. However, because of the nonlinguistic (i.e., social and political) connotations of unban, it should be given. 
One entry in William Branford 1987 says "see next entry," but the next one is completely irrelevant. This blind reference likewise came about as a result of deletion from an earlier edition.

Since etymologies are set off by brackets in this dictionary, a second marking (italics) is unnecessary, hence a marked font is needed in the etymologies only to contrast with the unmarked one. Thus "Ipresum. fr. half bottle]" would be sufficient, i.e., brackets indicate markedness (material so enclosed being marked [+ etymological information]); roman within an etymology is unmarked; and italics within an etymology indicate markedness visà-vis roman). If the linguistic convention of enclosing glosses in single quotation marks is followed, the lexicographer has three choices, which are probably all that are needed in an etymology, e.g., "[Afk. gril 'shudder']." The compilers do on occasion use single quotation marks to enclose glosses.

It is impossible to predict how the compilers will distinguish definiendum and definiens. Here, a comma separates the two. Usually there is no intervening punctuation; and in some places, the definiens is given in single quotation marks.

I.e., in English. In Afrikaans, it has a regular plural, Vaalpense.

South African English and Afrikaans should not be separated in this respect, for several words of Jewish interest in South African English have Afrikaans connections, e.g., gabba, smous, and (in this spelling) toggas (see note 21).

Jewish aspects of African languages of South Africa need study too. Two examples may be gleaned from the fourth edition of $A$ Dictionary of South African English: [i] s.v. jewish, this edition refers (blindly) to Zulu ijuwishi 'expensive dothing', a word derived from South African English jewish in its special South African sense; and [ii] one of the main entries is magata (the only information provided is "see gatas, gattes"; no such entry exists, but we do find one for gattes also gatas, die [sic] and one for gattes, where, however, nothing is said about magata). Perhaps it may be noted here that the compilers' suggested etymology of gattes also gatas, die, viz. "poss. fr. Sotho gata, to trample," does not seem to be satisfactory. Rather, die gattes / die gatas is from Afrikaans die gattes (Afrikaans gattes being of Yiddish origin).

We may expect items of Jewish interest in African languages of South Africa to be few because: [a] no Jews have been native or even primary or habitual users of these languages; [b] few Jews have even known any of these languages; and [c] for the most part, speakers of these languages perceive Jews in South Africa not specifically as Jews but as Whites (or as English-speakers or Afrikaans-speakers). Speakers of African languages thus have little occasion or need to speak of Jews qua Jews.

With regard to the last question, the fourth edition of A Dictionary of South African English follows my suggestion to Jean Branford that the etymology of schlenter 'a fake diamond sold as genuine...' and skolly 'a street hoodlum...' not contain any Jewish reference (some people have supposed these words to be of Yiddish origin or to have some other Jewish connection), inasmuch as no Jewish lect figures in their history and Jews had no part in their genesis (Gold 1984c). David B. Guralnik may have been the first to note (in Gold 1989b: 32) that Judeophobes tend to attribute a Jewish origin to lexemes referring to shady dealings or other improper behavior ("If it's a swindle, the swindlers must be Jews"). That may be the reason why some have sought a Jewish element in the etymology of schlenter, skolly, gazump, shyster (Gold 1989c), et simil. (Gold 1986b: 136 gives more English words supposedly but not really 
of Jewish origin). South African English goniza / gonizah 'a stolen or otherwise illicitly acquired diamond', on the other hand, does have a Jewish connection (though the etymology in the fourth edition is not correct) and snyde 'imitation [usually said of a diamond]' may have a Jewish connection.

In this edition, the etymology at mos 'indeed, in fact, actually, but' (also in for mos / for mos sie 'for no special reason, for the hell of it, just because') is "Afk. fr. Du. im(mers) 'indeed, in fact: thought by some to be fr. Yiddish mozel luck'." Yiddish mazl (sic recte) is indeed irrelevant and the word has no Jewish connection whatsoever. Earlier comments in Gold 1986a: 134.

On the value of negative etymologies in general, see $8 y p p o$ in section 6.

41 See, for example, Gold 1990a: 88 and Jewish Linguistic Studies 2: 538-539 on some parallels between Afrikaans and other languages.

42 In this case, I am allotopolectal with respect to South African English (being a native speaker of American English) and allolingual with respect to Afrikaans (being able to read the language but not to speak or write it). Jean Branford too has been interested in comparing South African English with another variety of English, that of Australia. Choice of which varieties to compare dictates the problems to be tackled and determines the results which the comparison might yield. Thus, to detect hitherto unrecorded items of Dutch origin in American English, South African English is the natural choice (and vice versa). Cf. the comment at can't complain in section 4.

43 For example, Jean Branford was unaware that suck out of the thumb was a distinctly South African English usage until $I$ called it to her attention (the expression makes its first appearance in the fourth edition of $A$ Dictionary of South African English, with citations from 1981 and 1985). The benefits of our relationship have flowed in both directions, for, thanks to her extensive reading program of South African material, she has been able to provide me with some of the citations used in my publications, where her help is acknowled ged numerous times. Mention should also be made of the unstinting assistance extended over many years by my chief consultants, Solly Rechtman and Heather Kemoff.

44 Skills and knowledge, not the superficial problem of gaining access to library and archival resources, are under discussion here. It is undeniably much easier to find material of Latin interest in the libraries and archives of Rome than of Tokyo, but given the option of being a good Latinist in Tokyo and a bad Latinist in Rome, one should the prefer the former. And with today's advances in information-retrieval, the problem of access to relevant material grows smaller every day.

45 Given the fact that most Jews in South Africa today trace their ancestry to what is now northem Lithuania, a smaller number to Latvia, Belarus, and the former Russian provinces of Lomza and Suvalki, and an even smaller number to other places, it is not surprizing that most of the Yiddish-origin items in contemporary Jewish South African English are specifically of Northeastern Yiddish origin (i.e., from the Yiddish of Northeastern Ashkenaz, which extends over present-day Lithuania, Latvia, Estonia, Belarus, northern Ukraine and northeastern Poland).

Older Jewish South African English had items of Western Yiddish origin, some of which may have survived to this day, i.e., even after people of Western Ashkenazic background became a minority in the South African Jewish community as a result of the larger Eastern Ashkenazic (mostly Northeastern Ashkenazic) immigration beginning at the end of the nineteenth 
century (as in the British Isles and the United States, where an earlier largely Western Ashkenazic community was later outnumbered by Eastern Ashkenazim, who by now have absorbed what remains of the earlier community almost entirely).

Western Yiddish (at first) and Northeastern Yiddish (later) are thus the two varieties of Yiddish which have been represented the most in South Africa (with Southern Yiddish being little represented). The stressed vocalism of Western Yiddish and Northeastern Yiddish often agree (grosso modo), in contrast to Southern Yiddish (which in many cases has innovative features not found in the stressed vocalism of those two varieties), so that it is sometimes hard to determine whether certain Yiddishisms in Jewish South African English are from Western Yiddish, Northeastern Yiddish, or both (no items are of Southern Yiddish origin). Four examples will suffice: the stressed vowels of beygl (with /ej/ and not /aj/), kugl (with $/ \mathrm{u} /$ and not $/ \mathrm{i} /$ or $/ \mathrm{l} /$ ), tokhes (with $/ \mathrm{o} /$ and not $/ \mathrm{u} /$ or $/ \mathrm{u} / \mathrm{c}$, and oover with $/ \mathrm{o} /$ and not $/ \mathrm{u} /$ or $/ \mathrm{u}: /$ ) could reflect either Western Yiddish or Northeastern Yiddish (but not Southern Yiddish) pronunciations, hence additional criteria, besides the stressed vowel, must be used for determining the source(s?) of these words:

[i] The earlier the word is attested in southern Africa (whether among Jews or non-Jews), the likelier it is to be of Western Yiddish origin (and the later it is first attested, the likelier it is to be of Northeastern Yiddish origin), that criterion being based on the fact that the earlier Jewish community in southern Africa was mostly of Western Ashkenazic origin and the later community mostly of Northeastern origin; and

[ii] If the etymon is not universal in Yiddish, its distribution may serve as a criterion. Thus, Jewish South African English kitke must be from Northeastern Yiddish because Yid. kitke is found only in that variety of the language. That criterion will not work for kugl and oover (which are found in both Western Yiddish and Northeastern Yiddish) and it will work only in part for tokhes (which is found in all of Northeastern Yiddish and in most of Western Yiddish, i.e., except in those varieties of Western Yiddish in which / $t /$ and / $d /$ have merged [as $/ d /$, hence the word in these varieties is pronounced /doxes/ and not / toxes/).

Criterion [i] is less certain than [ii], for words may be late in getting recorded (the fact that a word may be attested only from the time the Northeastem Ashkenazim became predominant in the South African Jewish community does not necessarily mean that it is of Northeastern, or only Northeastern, Yiddish origin, for it may date from the period of Western Ashkenazic predominance but just happen not to have been recorded until much later). Criterion [ii] is usually safer (kitke, for example, is indubitably of Northeastern origin for the reason just stated), but it too presents difficulties at times. An example is South African English beygl, which is certainly from Northeastern Yiddish, though it may, earlier, have been from Western Yiddish as well. The problem here is that we do not know whether Western Yiddish has the word.

Gabba, gattes, and smous are ultimately of Western Yiddish origin, though the exact path or paths which they traveled from Yiddish into South African English remains to be determined. Possible routes are through Rotwelsch, Dutch, German, British English and Afrikaans (needless to say, each word could have traveled a different route). These three words, in fact, are the most difficult South African English words of Jewish interest to etymologize. Gattes is discussed in Jewish Language Review 3: 318, 4: 402-403, and 6: 322. Smous is treated in Gold in preparation. 
Items of immediate Yiddish origin in Afrikaans and South African English (i.e., those which non-Jewish South Africans have borrowed from the speech of South African Jews) should be distinguished from those items which are of non-immediate, ultimate Yiddish origin (i.e., those which non-Jews brought from Europe to southem Africa). Kitke and smous are respec. tive examples: the first was introduced by Jews in southem Africa and the second, though ultimately of Yiddish origin, was brought by non-Jewish English-speakers and Dutch-speakers from Europe.

If it was non-Jews who brought the item to southem Africa, the makeup (Western Ashkenazic, Northeastern Ashkenazic, etc.) of the Jewish community there, at whatever time, is irrelevant to the genesis of the item (i.e., criteria [i] and [ii] do not apply). Smous (found in both Afrikaans and South African English) may serve as an example. Non-Jewish Dutch to this day and eighteenth-century British English have the offensive word smous 'sheeny, kike'. It was brought to southem Africa by non-Jewish speakers of English and of Dutch no later than 1786 (cf. p. xv of the fourth edition of A Dictionary of South African English, which says that a South African English citation from that year has been found), where it has undergone considerable semantic change, surviving in both Afrikaans and South African English to this day. Its history and survival in these two languages has nothing to do with the communal background of the Jewish community in South Africa - from the South African viewpoint, it is a word of immediate English and Dutch, not Yiddish, origin, brought from Europe, not borrowed from South African Jews. Therefore, even if not one Jew from English- or Dutchspeaking Europe had come to southern Africa, smous could still have entered Afrikaans, South African English, or both, because non-Jews coming from those parts of Europe could have brought it (and indeed did). The minimal requirement would probably be that southem Africa have had at least some Jewish inhabitants, for without Jews, no one would need a derogatory word for them (yet that is not a sine qua non: on anti-Jewish feeling in early-sixteenth-century Denmark, when no Jews were living in that country, see Edelman 1962).

See Gold 1985 on how error upon error is piled up when someone with no credentials in Jewish linguistios "reviews" a compilation, by a journalist with no credentials in Jewish linguistics, of superficial feature articles which he had published in The New York Times about people with no credentials in Jewish linguistics. Including Gold 1981b, 1981c, 1984b, and 1990c.

49 The label Jewish is defined as 'in use mostly among the Jewish group' (p. xxviii). It sounds a trifle Judeophobic (which was certainly not Jean Branford's intention when writing it, for I have known her to be absolutely free of prejudice). Ethnolectal labels (like this one, Black $E$., and Ind.E.) are not defined uniformly (pp. xxvii-xxix).

49 The compilers' notion that a kitke is "correctly known as challah in Hebrew" is based on their misinterpretation of an erroneous letter by a "Dr J.E. Kahn, London," which they quote s.v. kitke.

50 Before writing this review, I wondered how to cite from it: verbatim, as academic style requires, or with the changes necessary to make citations uniform and understandable. In most cases, the decision was to recast cited material for greater readability (without changing the meaning), though here and there, for example where no reasonable interpretation could be put on a passage (as at nonna in section 6), citation is verbatim. l thank Sol Steinmetz for comments on an earlier version of this review. 


\section{References}

Branford, Jean. 1978. A Dictionary of South African English. First Edition. Cape Town: Oxford University Press [rev. Gold 1986a and 1987b].

Branford, Jean. 1987. A Dictionary of South African English. Third edition. Cape Town: Oxford University Press [rev. Gold 1989a].

Branford, William. 1987. The South African Pocket Oxford Dictionary. Cape Town: Oxford University Press [rev. Gold 1987a].

Chapman, Rabert L. 1986. New Dictionary of American Slang. New York: Harper \& Row Irev. Gold 1990b].

Edelman, R. 1962. "Anti-Semitism in a Country Without Jews." Yioo-bleter XLII: 282-284.

Gold, David L. 1981a. "A Light Rain While the Sun Shines." American Speech 56: 159-160.

Gold, David L. 1981b. Review of Wood 1972. Jewish Language Review 1: 165.

Gold, David L. 1981c. "Three New-York-Cityisms: sliding pond, potsy, and akey." American Speech 56: 17-32.

Gold, David L. 1983. "Frequency Gallicism, Frequency Anglicism." Language Problems and Language Planning 7: 360-361.

Gold, David L. 1984a. "More on a Light Rain While the Sun Shines." Leuvense Bijdragen 73: 33-38.

Gold, David L. 1984b. "More on a Dutch-Origin Word in New York City English: sliding pon(d)." Lewoense Bijdragen 73: 171-175.

Gold, David L. 1984c. "English Etymological Miscellany: goop, the North River, skolly, shokh, kitke, schlenter." Leuvense Bijdragen 73: 315-334.

Gold, David L. 1985. Review of Murray 1984. Jewish Language Reoiew 5: 305-309.

Gold, David L. 1986a. "Two Desiderata for Lexicography: Allolingual and Allotopolectal Collaborators and the Philological Review (With Examples from Canadian, Bahamian, and South African English)." Dictionaries 8: 112-145.

Gold, David L. 1986b. "An Introduction to Jewish English." Jewish Language Reoiew 6: 94-120 [additions and corrections in 7: 622 and Jewish Linguistic Studies 2: 525-527].

Gold, David L. 1987a. Review of William Branford 1987. Jewish Language Review 7:264-269.

Gold, David L. 1987b. Review of Jean Branford 1978. Jewish Language Reoiew 7: 269-273.

Gold, David L. 1987c. Review of Major 1970. Jewish Language Reoiew 7: 357-358.

Gold, David L. 1989a. Review of Jean Branford 1987. Dictionaries 11: 242-260.

Gold, David L. 1989b. "On the Supposed Yiddish Origin of the English Noun gazump (With an Appendix on Other English Words of Yiddish or Supposed Yiddish Origin)." Jewish Linguistic Studies 1: 26-34 [additions and corrections in 2: 545-546].

Gold, David L. 1989c. "The English Noun shyster PTobably Has No Jewish Connection." Jewish Linguistic Studies 1: 35-41 [addition in 2: 546].

Gold, David L. 1990a. "Some Yiddish, Judezmo, and Hebrew Children's Counting-Out Rimes in Their European Context and Evidence Against the Suggestion That the First Line of the English Children's Counting-Out Rime eena meena mina mo May Be of São Tomense Origin." Jewish Linguistic Studies 2: 84-104.

Gold, David L. 1990b. "On Robert L. Chapman's New Dictionary of American Slang." Jewish Linguistic Studies 2: 134-158.

Gold, David L. 1990c. Review of Lanham and Prinsloo 1978. Jewish Linguistic Studies 2: 314-316. 
Gold, David L. to appear. "Twenty-Four Eastern Yiddish Words Meaning 'female genitals"." Jewish Linguistic Studies 3.

Gold, David L in preparation. "From Egyptian mes / mesu 'child; son' - By Way of Hebrew, Yiddish, Dutch, Afrikaans, and British English — to South African English smous / smouse 'to peddle goods'."

Gray, Christopher. 1992. "A Private-Dwelling Glossary." The New York Times, 5 April 1992, section 10: 9.

Lanham, L.W. and K.P. Prinsloo (Eds.). 1978. Language and Communication Studies in South Africa: Current Issues and Directions in Research and Inquiry. Cape Town: Oxford University Press.

Major, Clarence. 1970. Dictionary of Afro-American Slang. New York: International Publishers [rev. Gold 1987c].

Murray, Thomas E. 1984. Review of Shenker 1979. American Speech 59: 246-249.

Shenker, 1srael. 1979. Harmless Drudges: Wizards of Language - Ancient, Medizoal, and Modern. New York: Barnhart Books.

Wood, Richard E. 1972. "Dutch Syntactic Loans in Papiamentu." Revue des langues vivantes 38: 635-647 [rev. Gold 1981b]: 